\title{
TEKNIK PELUKISAN TOKOH UTAMA DALAM NOVEL HARAPAN DI ATAS SAJADAH KARYA MAWAR MALKA
}

\author{
oleh \\ Fitriani, Syahriandi, \& Masithah Mahsa* \\ *Dosen Program Studi Pendidikan Bahasa Indonesia, FT Universitas Malikussaleh \\ Surel: masithahmahsa@unimal.ac.id
}

\begin{abstract}
ABSTRAK
Penelitian ini bertujuan untuk mendeskripsikan teknik pelukisan tokoh utama yang digunakan dalam novel Harapan di Atas Sajadah Karya Mawar Malka. Pelukisan tokoh terbagi dua, yaitu teknik pelukisan tokoh secara langsung dan teknik pelukisan tokoh secara tidak langsung. Jenis penelitian yang digunakan dalam penelitian ini adalah deskriptif kualitatif. Penelitian ini dilakukan dengan menggunakan pendekatan objektif. Teknik pengumpulan data yang digunakan dalam penelitian ini ialah teknik baca catat. Hasil dari penelitian yang ditemukan dalam novel Harapan di Atas Sajadah karya Mawar Malka terdapat dua tokoh utama, yaitu Prasetya Anggara dan Adara Prasmaya. Data dari teknik pelukisan langsung berjumlah 15 data, sedangkan teknik pelukisan tidak langsung melalui teknik cakapan terdapat 11 data, tingkah lakusebanyak 12 data, pikiran dan perasaan sebanyak 8 data, arus kesadaran sebanyak 5 data, reaksi tokoh sebanyak 11 data, reaksi tokoh lain sebanyak 3 data, pelukisan latar sebanyak 3 data, pelukisan fisik sebanyak 2 data, dan catatan tentang identifikasi tokoh sebanyak 2 data.
\end{abstract}

\section{Kata Kunci: Novel Harapan di Atas Sajadah, Teknik Pelukisan Tokoh, Tokoh Utama}

\section{PENDAHULUAN}

Karya sastra merupakan hasil kreatif manusia yang selalu berusaha mengekspresikan nilai-nilai kemanusiaan sesuai dengan peradaban dalam masyarakat. Karya sastra sendiri mempunyai bentuk, ciri dan syarat-syarat yang bermacam-macam. Salah satu bentuk dari karya sastra antara lain adalah novel. Novel merupakan salah satu bentuk kesusastraan yang paling banyak digemari oleh setiap masyarakat dewasa ini. Novel merupakan salah satu hasil karya sastra yang mencerminkan kehidupan dan mengungkapkan nilai-nilai kehidupan masyarakat yang banyak memberikan manfaat. Persoalan atau permasalahan kehidupan manusia yang disajikan dalam sebuah novel dituliskan secara tersirat maupun tersurat yang bersifat universal. Masalah yang diangkat dalam sebuah novel merupakan refleksi atau pantulan dari permasalahan yang terjadi pada masyarakat dalam dalam kehidupan sehari-hari. Sebuah cara untuk dapat memahami dan menghayati nilai-nilai dalam sebuah novel pembaca harus berusaha untuk mengenal struktur dan unsur-unsur yang membangun sebuah novel. Unsur-unsur pembangun dalam sebuah novel ada dua yaitu unsur intrinsik dan unsur ekstrinsik.

Salah satu unsur intrinsik ialah penokohan. Penokohan merupakan salah 
satu faktor terpenting dalam sebuah cerita fiksi. Penokohan adalah cara pengarang dalam menampilkan gambaran yang jelas tentang seorang tokoh dalam dalam sebuah cerita. Penokohan dalam sebuah karya sastra digunakan pengarang untuk menyampaikan gagasan dan perasaannya tentang suatu hal yang terjadi dalam sebuah novel. Pengarang dapat menceritakan banyaknya permasalahan dalam sebuah novel melalui situasi yang berbeda-beda disebabkan adanya pelukisan tokoh. Penokohan mempunyai kekuatan untuk menguasai keseluruhan isi cerita dalam sebuah novel. Penentuan jalan cerita dalam sebuah novel sangat bergantung pada penokohan, tanpa adanya penokohan dan kelakuan tokoh dalam sebuah novel tidak ada artinya (Karmini, 2011:17).

Pada saat membaca sebuah novel, seseorang dapat merasakan peran kehidupan dari masing-masing tokoh terutama tokoh utama. Pengarang menuliskan sebuah novel bukan sekadar untuk menimbulkan perasaan senang kepada pembaca melainkan juga menyampaikan sebuah pesan tentang kejadian yang diukiskan melalui sikap tokoh dalam sebuah novel. Kejadian tersebut dapat dilihat melalui peran yang dimiliki seorang tokoh utama dalam sebuah cerita.

Setiap tokoh utama memiliki peran yang berbeda dan mengalami perubahan tingkah laku. Tokoh dalam sebuah cerita akan mengalami perubahan tingkah laku dari awal, tengah, dan akhir cerita sesuai dengan tuntutan jalan cerita secara keseluruhan dalam sebuah novel. Tanpa adanya perubahan tingkah laku, novel menjadi kurang menarik dan membosankan para pembaca. Oleh karena itu,untuk memahami karya sastra khususnya pelukisan tokoh utama diperlukan analisis terhadap bagian alur atau jalannya cerita dalam sebuah novel. Penulis tertarik dengan novel ini karena permasalahan yang ditampilkan sering terjadi dalam sebuah keluarga yaitu kurangnya rasa kepedulian terhadap istri akibat perjodohan. Selain itu, Mawar Malka juga memiliki kelebihan dari penulis lainnya. Kelebihan yang dimiliki oleh pengarang sendiri adalah pengarang dapat menggambarkan dengan detail setiap kejadian yang ada dalam karangannya dan menggunakan kata-kata yang bersifat eksplisit. Akibatnya, pembaca dapat larut dan terbawa kedalam kisah tersebut, seolah-olah sedang merasakan kejadian yang sedang dibaca. Bahasa yang digunakan lebih puitis dan penuh personifikasi. Hal tersebut membuat hasil karya Mawar Malka tidak membosankan para pembaca.

Novel Harapan di Atas Sajadah karya Mawar Malka merupakan salah satu novel yang mengisahkan tentang kehidupan yang harus dijalani dengan rasa optimisme. Novel ini menceritakan kisah kehidupan tokoh utama yang memiliki goncangan jiwa akibat kematian kedua orang tuanya. Adara adalah anak satusatunya dan sangat dimanjakan oleh kedua orang tuanya terpaksa harus menerima kehidupan di panti asuhan. Kepahitan dalam kehidupan menuntut dirinya untuk menjadi kepribadian yang mandiri. Akibat peristiwa yang terjadi membuat Adara sadar dan berubah menjadi lebih baik. Bahkan, setelah menikah Adara mendapatkan ujian kehidupan yang sangat besar. Akan tetapi, semangat Adara tidak pernah pudar karena Adara tahu kasih dan sayang Sang Maha Kuasa di atas sajadah lebih indah dari segalanya. Oleh karena itu, untuk mengetahui tentang sikap tokoh dalam novel, peneliti mengkaji tentang Teknik Pelukisan Tokoh Utama dalam Novel Harapan di Atas Sajadah Karya Mawar Malka.

Penelitian tentang teknik penokohan sangat penting dilakukan untuk mengetahui penggambaran sikap tokoh yang dilukiskan pengarang dalam sebuah novel. Masalah penokohan dalam sebuah karya tidak semata-mata hanya 
berhubungan dengan masalah pemilihan jenis perwatakan para tokoh cerita saja, melainkan juga bagaimana melukiskan kehadiran tokoh secara tepat sehingga mampu menciptakan dan mendukung tujuan artistic karya yang bersangkutan. Hal ini dikarenakan teknik pelukisan tokoh adalah dasar dari sebuah acuan untuk terbentuknya seorang tokoh dalam novel. Hal ini sejalan dengan penelitian yang dilakukan oleh Sesilia (2015) dengan judul Teknik Pelukisan Tokoh dalam Novel Hujan Bulan Juni Karya Sapardi Djoko Damono, yang mengatakan bahwasanya penelitian tentang teknik pelukisan tokoh merupakan sebuah cara untuk menghadirkan, menggambarkan dan melukiskan ciri kedirian tokoh dalam sebuah cerita.

Novel Harapan di Atas Sajadah merupakan novel terbitan terbaru dan belum pernah diteliti oleh orang lain. Cara untuk mengetahui teknik pelukisan tokoh dalam novel Harapan di Atas Sajadahadalah dengan menggunakan teknik ekspositori dan Teknik dramatik. Hal ini didukung oleh penelitian sebelumnya dengan judul Analisis Tokoh dan Penokohan dalam Novel Sepatu Dahlan Karya Khrisna Pabicharaoleh Ucha (2016), yang menemukan bahwa untuk mendeskripsikan peran, watak dan teknik penokohan yang terdapat dalam novel Sepatu Dahlan karya Khrisna Pabichara meliputi Teknik ekspositori/analitik (langsung) dan teknik dramatik (tidak langsung).

Pengarang mengangkat cerita dalam novel ini tentang masalah perjodohan, dimana salah satu diantara tokoh utama tidak menerima tentang sebuah ikatan perjodohan tersebut. Masalah perjodohan memang tidak pernah berhenti dibicarakan, sampai saat ini perjodohan masih saja menjadi gagasan hangat bagi para pengkaji sastra. Hal ini dibuktikan oleh penelitian Rendra (2015) dengan judul Masalah Perjodohan dalam Novel Memang Jodoh Karya Marah Rusli, yang mengatakan bahwa perjodohan di antaranya adalah perkawinan paksa. Di samping itu, masalah perjodohan ini dipicu karena adanya orang ke tiga atau biasanya orang tua yang memaksa anaknya untuk menikah.

Berdasarkan beberapa alasan di atas, maka judul dalam penelitian ini adalah Teknik Pelukisan Tokoh Utama dalam Novel Harapan di Atas Sajadah Karya Mawar Malka. Judul ini sesuai dengan penjabaran alasan dan permasalahan yang telah dibahas di atas. Oleh karena itu, peneliti tertarik untuk mengkaji tentang teknik pelukisan tokoh utama dalam novel Harapan di Atas Sajadah Karya Mawar Malka.

\section{TINJAUAN TEORITIS Pengertian Novel}

Novel merupakan salah satu karya sastra yang berbentuk prosa, di dalamnya disajikan permasalahan secara kompleks dan terperinci. Sebuah novel biasanya diawali dengan cerita dari sebuah kejadian atau peristiwa penting yang dialami oleh tokoh dalam cerita. Novel juga menceritakan tentang kehidupan manusia yang menonjolkan sifat dan watak setiap pelaku. Pengarang berusaha semaksimal mungkin untuk mengarahkan pembaca kepada berbagai macam gambaran realita kehidupan melalui cerita yang terkandung di dalam novel tersebut.

Nurgiyantoro

(2017:18)mengemukakan bahwa novel adalah karya yang bersifat realistis dan mengandung nilai psikologi yang mendalam. Maksudnya, novel merupakan hasil karya imajinasi pengarang yang bersifat terbuka dan sesuai dengan kenyataan sebenarnya. Sesuatu yang menjadi bagian dalam kehidupan manusia, yang mengandung nilai-nilai luhur agar dapat diaplikasikan bagi kehidupan para pembacanya. Sejalan dengan itu, Kosasih (2014:299) mengemukakan bahwa novel adalah karya imajinatif yang mengisahkan sisi utuh atas 
problematika kehidupan seseorang atau beberapa orang tokoh. Maksudnya novel merupakan sebuah karya cipta manusia yang diwujudkan oleh seorang penulismelalui penggambaran berbagai kisah hidup yang dialami seseorang tokoh. Sifat baik atau buruk yang muncul dalam kehidupan sang tokoh, kemudian diceritakan dalam karya satra berbentuk novel.

\section{Unsur Intrinsik Novel}

Unsur intrinsik adalah unsur-unsur yang membangun sebuah karya sastra. Menurut Nurgiyantoro (2017:30) bahwa unsur-unsur intrinsik meliputi tema, plot/alur, amanat, latar, sudut pandang, gaya bahasa, perwatakan/penokohan. (Ismaiyati dalam Wahyuni 2017:7) mengungkapkan bahwa tema adalah ide yang mendasari suatu cerita sehingga berperan juga sebagai pangkal utama pengarang dalam menciptakan sebuah karya fiksi. Tema dipandang sebagai dasar cerita atau gagasan pokok yang dikemukakan oleh pengarang dalam sebuah karya fiksi melalui cerita yang ditulisnya. Melalui ide dasar itulah pengarang menciptakan sebuah cerita. Aftrianti (2014:17) menjelaskan bahwa alur adalah struktur rangkaian kejadian dalam sebuah cerita yang di susun sebagai sebuah interelasi fungsional yang sekaligus menendai urutan bagian-bagian dalam keseluruhan fiksi. Alur atau plot adalah jalinan peristiwa atau kejadian dalam suatu karya sastrauntuk mencapai efek tertentu.

Kosasih (2014:307) menjelaskan bahwa amanat adalah pesan yang disampaikan pengarang kepada pembaca melalui tulisannya, sehingga pembaca dapat menarik kesimpulan dari apa yang telah dibaca. Amanat adalah pesan moral yang ingin disampaikan penulis kepada pembaca berupa nilai-nilai luhur yang dapat dijadikan contoh atau teladan. Latar disebut juga setting. Latar adalah segala keterangan, pengacuan, atau petunjuk yang berkaitan dengan tempat, waktu dan situasi terjadinya peristiwa dalam suatu cerita. Latar berfungsi sebagai pemberi kesan realistis kepada pembaca. Hal ini didukung oleh pendapat (Abrams dalam Nurgiyantoro, 2018:302) yang mengemukakan secara garis besar deskripsi latar atau settingdapat dikategorikan dalam tiga bagian yaitu, menyarankan pada pengertian tempat, hubungan waktu, dan lingkungan sosial tempat terjadinya peristiwa yang diceritakan.

Abrams (dalam Nurgiyantoro, 2017:338) mengemukakan sudut pandang adalah cara atau pandangan yang digunakan oleh pengarang sebagai sarana untuk mengetahui penyajikan tokoh, tindakan, latar dan berbagai peristiwa yang membentuk cerita dalam sebuah karya fiksi kepada pembaca. Sudut pandang adalah arah pandangan seseorang penulis dalam menyampaikan sebuah cerita, sehingga cerita tersebut lebih hidup dan tersampaikan dengan baik pada pembaca atau pendengarnya. Nurgiyantoro (2017:340-357) menyebutkanbeberapa sudut pandangyang dapat digunakan pengarang dalam bercerita,antara lain sebagai berikut; (a) Sudut pandang orang pertama, sudut pandang ini biasanya menggunakan kata ganti aku. Dalam hal ini, pengarang seakan-akan terlibat dalam cerita dan bertindak sebagai tokoh cerita; (b) Sudut pandang orang ketiga, sudut pandang ini biasanya menggunakan kata ganti orang ketiga seperti dia, ia, atau nama orang yang dijadikan sebagai titik berat cerita; (c) Sudut pandang pengamat serba tahu, dalam hal ini pengarang bertindak seolah-olah mengetahui segala peristiwa yang dialami tokoh dan tingkah laku tokoh; (d) Sudut pandang campuran, (sudut pandang orang pertama dan pengamat serba tahu).

Terkait dengan gaya bahasa, Kosasih (2014:309) mengemukakan gaya bahasa adalah cara pengarang 
mengungkapkan isi pikirannya melalui bahasa-bahasa yang khas, sehingga bisa menimbulkan suatu kesan tertentu yang diperlihatkan melalui interaksi antartokoh. Penggunaan gaya bahasa yang tepat bisa menarik perhatian pembaca. Gaya bahasa bisa menghidupkan apa yang dikemukakan dalam tulisan atau pembicaraan, karena gaya bahasa mengemukakan kata-kata yang penuh dengan makna.

Tokoh dan penokohan adalah unsur yang sangat penting dalam sebuah novel (Na $\left.{ }^{e \mathrm{im}}, 2016: 2\right)$. Tokoh dan penokohanlah yang menjadi dasar pengarang dalam menggambarkan karangannya. Tanpa hadirnya tokoh dan penokohan dalam sebuah karya maka tulisan tersebut tidak ada artinya karena tidak ada daya untuk menarik perhatian pembaca. Penokohan adalah cara pengarang menggambarkan atau melukiskan tokoh dalam cerita yang ditulisnya. Dalam penokohan, watak atau karakter tokoh dapat dilihat melalui dialog tokoh, penjelasan tokoh, dan penggambaran fisik tokoh. Tokoh dan penokohan dalam sebuah cerita sangat erat kaitannya sebab perwatakan tokoh digambarkan melalui penampilan tokoh. Sesuai dengan pendapat Nurgiantoro (2017:247) memaparkan bahwa penokohan menunjuk pada penempatan tokoh-tokoh tertentu dengan watak tertentu dalam sebuah cerita. Perwatakan dilihat melalui gambaran, baik tindakan maupun ucapan sejalan atau tidak antara yang dikatakan dengan yang dilakukan.

\section{Teknik Pelukisan Tokoh}

Teknik pelukisan tokoh juga dikenal dalam dunia fiksi. Wiyatmi (2009:32) mengungkapkan bahwa cara sastrawan menggambarkan atau memunculkan tokohnya dalam sebuah cerita terdapat beberapa cara. Cara tersebut ada dua, yaitu secara langsung (telling, analitik) dan secara tidak langsung (showing, dramatik). Secara langsung teknik analitis atau sering juga disebut teknik ekspositori adalah Teknik melukiskan tokoh dengan memberikan deskripsi atau penjelasan secara langsung. Secara tidak langsung atau sering disebut dengan teknik dramatik adalah suatu cara yang digunakan pengarang secara eksplisit, sifat dan sikap serta tingkah laku tokoh tidak dideskripsikan secara langsung.

Minderop (2011:6) mengatakan bahwa menyajikan dan menentukan karakter (watak) para tokoh,pada umumnya pengarang menggunakan dua cara atau metode dalam karyanya. Pertama metode langsung (telling) dan kedua metode tidak langsung (showing). Metode langsung (selling) pemaparannya dilakukan secara langsung oleh pengarang. Metode ini biasanya digunakan oleh kisah-kisah rekaan zaman dahulu sehingga pembaca hanya mengandalkan penjelasan yang dilakukan pengarang semata. Metode langsung atau direct method meliputi karakterisasi melalui penggunaan nama tokoh,melalui penampilan tokoh,dan melalui tuturan pengarang. Metode tidak langsung adalah metode dramatik yang mengabaikan kehadiran pengarang,sehingga para tokoh dalam karya sastra dapat menampilkan diri secara langsung melalui tingkah laku mereka. Metode dramatik meliputi: karakterisasi melalui dialog, lokasi dan situasi percakapan, jati diri tokoh yang dituju oleh penutur, kualitas mental para tokoh, nada suara, tekanan, dialek, dan kosakata, yang terakhir karakterisasi melalui tindakan para tokoh.

$$
\text { Nurgiyantoro }
$$

menyebutkan bahwa pelukisan tokoh dalam suatu karya dapat dibedakan ke dalam dua cara, yaitu Teknik ekspositori dan teknik dramatik. Kedua teknik tersebut masing-masing mempunyai kelebihan dan kekurangan. Penggunaannya dalam sebuah karya fiksi tergantung pada selera pengarang. Teknik langsung lebih banyak digunakan 
pengarang pada masa awal pertumbuhan dan perkembangan novel Indonesia modern, sedangkan teknik tidak langsung terlihat lebih diminati oleh pengarang dewasa ini.

\section{METODE PENELITIAN}

Penelitian sastra ini menggunakan metode deskriptif kualitatif. (Sudaryanto dalam Priyambada, 2017:24) mengemukakan bahwa istilah deskriptif menyarankan pada suatu penelitian yang semata-mata hanya berdasarkan pada fakta-fakta yang ada, sehingga apa yang dihasilkan dan dicatat berupa uraian bahasa yang mencerminkan sifatnya. Data yang dikumpulkan berupa kosakata, kalimat dan gambaran yang mempunyai arti. Hal ini dikarenakan data hasil penelitian diuraikan dengan tidak mengutamakan angka-angka. Data dalam penelitian ini berupa kata-kata, kalimat dan kutipan teks/dialog yang dapat menunjukkan teknik pelukisan tokoh utama dalam novel Harapan di Atas Sajadah karya Mawar Malka.Sumber data dalam penelitian ini adalah novel Harapan di Atas Sajadah karangan dari Mawar Malka, cetakan pertama, tebal halaman 542, pada tahun 2018, yang diterbitkan oleh Wahyu Qolbu. Teknik pengumpulan data dalam penelitian ini menggunakan teknik baca dan teknik catat. Adapun teknik analisis data yaitu: (a) Peneliti menbaca dan memberi kode, lalu mencatat data-data yang mencerminkan teknik pelukisan tokoh utamayang terdapat dalam novel Harapan di Atas Sajadah karya Mawar Malkatersebut; (b) Peneliti mengelompokkan data-data yang mencerminkan teknik pelukisan tokoh utama dalam novel Harapan di Atas Sajadah karya Mawar Malka; dan (c) Peneliti menguraikan data-data tersebut, kemudian menganalisis/mendeskripsikan teknik pelukisan tokoh utama dalam novel Harapan di Atas Sajadah karya Mawar Malka.

\section{HASIL PENELITIAN}

Berdasarkan hasil penelitian, data yang dianalisis pada penelitian ini adalah Teknik pelukisan secara langsung dan tidak langsung dalam novel Harapan di Atas Sajadah karya Mawar Malka. Teknik pelukisan tokoh digunakan oleh pengarang dalam karyanya untuk mempermudah pembaca dalam menanggapi dengan tepat dan jelas tentang bagaimana melukiskan kedirian yang melekat pada diri tokoh yang bersangkutan. Ada banyak data yang ditemukan dalam penelitian, beberapa akan dijabarkan sebagai berikut.

\section{a. Teknik Pelukisan Langsung}

Teknik pelukisan langsung dapat mengurangi kesalahan pemahaman dari seorang pembaca. Namun, sang pengarang harus tetap mempertahankan karakter yang dapat mencerminkan pola kedirian dari tokoh yang bersangkutan. Kekurangan dari teknik penokohan ini adalah pembaca tidak ikut serta secara aktif berpikir dan menafsirkan sendiri karakter-karakter dalam cerita. Berikut ini adalah tokoh utama yang digambarkan menggunakan teknik pelukisan tokoh secara langsung:

\section{Prasetya Anggara}

Berikut ini beberapa data yang menjelaskan kedirian tokoh Pras yang digambarkan oleh Malka dalam novelnya.

"Pemuda angkuh itu masuk kedalam mobil. Duduk sambil melipat lengannya. Satu kancing teratasnya ia buka. Rambut yang basah ia sisir dengan jari." (Malka, 2018:8).

Kutipan di atas menggambarkan kedirian tokoh Pras. Pras digambarkan sebagai tokoh yang angkuh secara langsung melalui Kalimat "Pemuda angkuh itu masuk kedalam mobil" melukiskan tentang sikap yang dimiliki tokoh Pras. Pras digambarkan dengan sikap angkuh yang melekat pada dirinya, sehingga siapa saja yang membaca novel ini akan mudah memahami sikapnya 
melalui teknik pelukisan tokoh secara langsung.

Malka menyadari akan hal menariknya sebuah novel dikarenakan adanya tokoh protagonis dan tokoh antagonis. Maka dari itu, novel ini disajikan tokoh Pras sebagai tokoh antagonis agar terlihat lebih menarik. Tidak hanya dengan tokoh lain, Malka juga menggambarkan tokoh Pras yang sedang emosi terhadap orang tuanya. Berikut data yang membuktikan hal tersebut.

"Pras yang sendirian menggepalkan tangannya. Ia mencoba untuk menenangkan degup jantungnya yang berdetak cepat karena emosi." (Malka, 2018:19).

Sejalan dengan kutipan di atas, Malka melukiskan tokoh Pras yang sedang dilanda emosional. Orangtuanya mau menjodohkan Pras dengan wanita pilihan mereka, sedangkan Pras tidak pernah menyukai wanita lain selain wanita yang ada dalam hatinya saat ini. Kalimat "Ia mencoba untuk menenangkan degup jantungnya yang berdetak cepat karena emosi" membuktikan bahwa Pras sedang marah terhadap kedua orang tuanya. Orangtuanya mengancam Pras untuk menuruti kemauannya, jika tidak semua harta kekayaan papanya akan disumbangkan ke panti asuhan. Malka menggambarkan tokoh Pras yang sedang dilanda frustrasi dan bigung untuk menentukan pilihan yang diberikan oleh kedua orangtuanya. Bagaimanapun caranya, Pras mulai berpikir terhadap semua harta warisan harus jatuh ke tangannya. Seiring berjalannya cerita Malka menggambarkan tokoh Pras yang pasrah terhadap permintaan kedua orangtuanya. Pras terpaksa menyetujui permintaan mereka demi mendapatkan harta warisan.

2. Adara Prasetya

Dalam novel ini Adara juga digambarkan sebagai tokoh utama. Adara merupakan tokoh utama yang diceritakan untuk melengkapi kehidupan tokoh Pras. Adara selalu muncul di setiap bab yang diceritakan karena tokoh utama adalah tokoh yang paling sering muncul. Sebagai tokoh utama dalam sebuah cerita tentu saja banyak teks yang menceritakan tentang penampilan dari tokoh Adara. Malka menuliskan kutipan lainnya yang menceritakan tentang penampilan tokoh Adara secara langsung. Berikut data yang bisa mencerminkan tokoh Adara melalui ucapan tokoh lain untuk menjelaskan kediriannya.

"Ekmm...dia seorang Gadis suci, Nak. Dia memakai cadar, dan hebatnya lagi, dia seorang hafizhah. Itu apa namanya, penghafal Qurean. Kalian hanya bisa bertemu setelah akad nikah, setelah ijab-qabul, ujar sang Mama yang agak bingung juga menjelaskannya." (Malka, 2018:20).

Kutipan di atas menggambarkan tentang kebingungan dari tokoh Adara. Kalimat "dia seorang gadis suci, Nak. Dia memakai cadar, dan hebatnya lagi, dia seorang hafizhah" menjelaskan bahwa tokoh Adara adalah tokoh yang baik. Malka menggambarkan tokoh Adara yang menyimpang dari tokoh Pras, dikarenakan untuk adanya daya tarik dalam sebuah cerita. Penampilan Adara digambarkan sebagai perempuan yang berasal dari pesantren yang memakai cadar dan bisa menghafal Al-Qurean. Malka melukiskan kedirian tokoh Adara tentang kelebihan yang ia miliki, selain cantik dia juga dia juga memiliki kelebihan terhadap kepintarannya.

Beberapa data untuk teknik pelukisan secara langsung memang menggunakan data yang melukiskan tentang kedirian dari tokoh Adara. Pras sebagai tokoh utama juga sering menggambarkan tentang kedirian dari tokoh Adara. Berikut data yang berkaitan 
dengan kedirian tokoh Adara yang digambarkan melalui tokoh Pras.

"Pras tahu gadis yang sudah menjadi istrinya itu tidak memakai bulu mata buatan dan juga tidak memakai eye shadow dan make up tebal, tetapi ia tahu istrinya cukup cantik dengan bulu mata asli yang tebal dan mata yang bulat sempurna."

(Malka, 2018:27).

Teks di atas melukiskan melukiskan tentang gambaran tokoh Adara melalui kecantikannya. Kutipan di atas dapat dikategorikan melalui kedirian tokoh Adara dalam penggambaran fisiknya. Kalimat "gadis yang sudah menjadi istrinya itu tidak memakai bulu mata buatan dan juga tidak memakai eye shadow dan make up tebal, " menjelaskan tentang pelukisan fisik Adara. Malka menggambarkan tokoh Adara yang memiliki kecantikan alami tanpa perlu dihiasi dengan make up melalui kedirian tokoh Pras. Melalui teknik ini pembaca dapat langsung mengetahui kedirian dari tokoh Adara yang memiliki penampilan fisik yang menawan dan terlihat cantik tanpa polesan.

\section{b. Teknik Pelukisan Tidak Langsung}

Pada teknik pelukisan tidak langsung, pengarang tidak mendeskripsikan secara eksplisit tentang sifat serta tingkah laku dari seorang tokoh. Untuk mengetahui watak seorang tokoh pembaca harus menafsirkan sendiri tentang ucapan, pikiran, perbuatan, bentuk fisik, reaksi yang dapat mencerminkan tentang kedirian dari diri tokoh tersebut. Pengarang membiarkan para tokoh yang ada dalam cerita untuk memperlihatkan karakternya melalui tingkah laku, peristiwa yang terjadi dan sebagainya. Teknik penokohan ini lebih efektif dari pada teknik penokohan analitis. Teknik pelukisan tokoh secara tidak langsung terdapat sembilan teknik, yaitu teknik cakapan, teknik tingkah laku, teknik pikiran dan perasaan, teknik arus kesadaran, teknik reaksi tokoh, teknik reaksi tokoh lain, teknik pelukisan latar, teknik pelukisan fisik, dan catatan tentang identifikasi tokoh (Nurgiyantoro, 2017:283-297). Berikut ini dipaparkan teknik pelukisan kedalam pembagian yang disebutkan oleh Nurgiyantoro.

\section{Teknik Cakapan}

Tidak semua percakapan dapat mencerminkan kedirian tokoh dalam sebuah novel, tetapi ada beberapa percakapan yang mengarahkan pada kedirian seorang tokoh. Percakapan yang dimaksud adalah percakapan yang dapat memberikan gambaran tentang karakternya. Data yang didapatkan tentang teknik cakapan ini biasanya berupa dialog yang dilakukan oleh tokoh dalam sebuah novel.

a) Prasetya Anggara

Sebagai tokoh utama, tentunya segala interaksi dari Pras akan dituliskan. Akan tetapi tidak semua percakapan dari tokoh Pras bisa dijadikan sebagai data untuk teknik cakapan karena ada percakapan yang tidak bisa menggambarkan tentang kedirian dari tokoh tersebut. Ada beberapa data di bawah ini yang dapat dijadikan sebagai Teknik cakapan dari tokoh Pras. Data yang dimaksud adalah sebagai berikut.

"Pras menoleh pada mamanya. Mama serius?! Nggak bisa, Pa, Ma. Ini gila namanya!” teriak Pras. "apanya yang nggak bisa, Pras? Apanya yang gila?" sela Andi dengan pertanyaan.

"Papa sama Mama mau nikahin aku dengan orang yang sama sekali aku nggak tahu. Gilanya lagi, dia bercadar. Apa kata teman-teman aku, pa, aku punya istri bercadar?" (Malka, 2018:20).

Kutipan di atas adalah percakapan Pras dengan orang tuanya. Ucapan dari Pras secara tidak langsung membuat pembaca mengetahui sifat malu dari tokoh Pras. Ucapan "Ngak bisa, Pa, Ma. Ini gila 
namanya!" menggambarkan tentang sikap Pras yang tidak bisa menerima tentang perjodohan dari orang tuanya. Pras kembali menegaskan kalimat "Apa kata teman-teman aku pa, aku punya istri bercadar?!'Menjelaskan bahwa Pras malu saat dilihat oleh teman-temannya bahwa dia memiliki istri bercadar. Malka menggambarkan tokoh Pras yang tidak menyukai terhadap wanita bercadar. Namun, kedua orangtua Pras tetap akan menjodohkan dirinya dengan Adara. Karakter Pras yang marah ditambah dengan sikap malu dapat dilihat melalui percakapan di atas dengan menggunakan teknik cakapan secara tidak langsung. Selain data di atas, data di bawah ini juga menggambarkan tentang pelukisan tokoh Pras secara tidak langsung melalui percakapan. Data yang dimaksud adalah sebagai beriku.

“Apa peduli lo, hah?! Nggak usah muna deh jadi cewek, ini apa ini?!

Cadar? Buat nutupin kebusukan lo?! Lo nikah ma gue karna harta gue, ya kan?!” (Malka, 2018:41).

Data di atas menjelaskan tentang sifat yang dimiliki Pras. Malka menggambarkan tentang karakter yang dimiliki tokoh Pras melalui perkataan. Melalui pertanyaan "ini apa ini?! Cadar? Buat nutupin kebusukan lo?!" menggambarkan tentang sifatnya yang tidak memikirkan tentang perasaan orang lain. Sewaktu berbicara Pras tidak pernah menghargai seseorang. Seolah-olah dirinya adalah orang yang sangat beruntung dan bisa mendapatkan semua kemauannya tanpa bantuan orang lain. Pras menunjukkan sikap keangkuhannya terhadap seorang istri yang tidak memiliki apa-apa. Akan tetapi, sang istri hanya dapat bersabar melihat tingkah suaminya yang semakin hari semakin menjadi-jadi.

b) Adara Prasetya

Pelukisan tokoh terhadap Adara memang selalu dilukiskan oleh pengarang dengan bersikap baik. Akan tetapi, Malka juga menyadari bahwa tokoh yang baik ada saatnya untuk bersikap tegas dan teguh pada pendiriannya. Berikut ini data yang dapat menggambarkan tentang sikap tegas dari tokoh Adara.

"Aku memang istrimu, Mas. Bahkan ucapanmu adalah kewajiban untuk aku turuti, tapi maaf, aku tetap pada pendirianku dengan hijab dan cadarku. Ini adalah janjiku, sebelum Mas Pras menerima aku apa adanya, aku tidak akan melepas cadar ini." (Malka, 2018:80).

Data di atas dapat menggambarkan kedirian dari tokoh Adara tentang sikap tegas. Ucapan yang sedang dilakukan Adara dapat melukiskan tentang sikap tegasnya kepada sang suami. Kalimat "Bahkan ucapanmu adalah kewajiban untuk aku turuti, tapi maaf, aku tetap pada pendirianku dengan hijab dan cadarku" menjelaskan tentang kedirian Adara. Adara tidak mau menuruti permintaan Pras untuk membuka cadarnya. Sebelum sang suami menerima dirinya layaknya perempuan-perempuan lain yang menjadi seorang istri, Adara tidak akan membuka cadarnya. Secara tidak langsung melalui teknik daramatik khususnya percakapan tokoh pembaca dapat mengetahui tentang sikap Adara yang dilukiskan sebagai tokoh yang baik, namun memiliki sikap tegas. Tokoh Adara digambarkan sebagai tokoh yang teguh pada pendiriannya dan tidak akan pernah berubah terhadap keputusan yang sudah dilakukannya.

Pengarang juga menngambarkan tentang sikap penyayang yang dimiliki oleh tokoh Adara. Adara dilukiskan sebagai tokoh yang memiliki rasa kasih sayang terhadap ibu angkat yang pernah mengasuhnya diwaktu kecil. Data yang dimaksud untuk menggambarkan sikap Adara yang penyayang adalah sebagai berikut.

"Apa kabarmu, Nak?"

Adara tersenyum. "Aku baik-baik saja, Bu. Aku mengkhawatirkan Ibu. Aku dengar 
Ibu sakit, makanya aku ke sini." "Ibu nggak apa-apa, Nak. Ayo duduk." (Malka, 2018:129).

Kutipan di atas menggambarkan tentang sikap Adara sebagai tokoh utama yang memiliki sikap peduli kasih sayang terhadap seseorang. Tokoh yang baik memang selalu digambarkan untuk berbuat baik dan disukai oleh banyak pembaca. Kalimat "Aku mengkhawatirkan Ibu" menjelaskan bahwa tokoh Adara masih mempunyai rasa iba terhadap seseorang. Adara masih mengingat tentang jasa dari ibu angkatnya yang dulu pernah bersusah payah mengasuhnya waktu kecil. Oleh karena itu, data di atas menggambarkan tentang tokoh Adara yang pulang ke kampung halamannya untuk menjenguk ibunya yang sedang sakit. Secara tidak langsung pembaca dapat mengetahui tentang tokoh Adara yang mamiliki sifat penyayang dan digambarkan melalui teknik dramatik.

\section{Teknik Tingkah Laku}

Teknik tingkah laku adalah teknik yag dilukiskan oleh pengarang terhadap seorang tokoh melalui perbuatannya. Teknik ini digunakan untuk menunjukkan reaksi, tanggapan, sifat dan sikap yang mencerminkan kedirian dari tokoh yang melakukan reaksi tersebut. Jika teknik cakapan yang dimaksud untuk menunjukkan tingkah laku verbal yang berwujud kata-kata para tokoh, teknik tingkah laku menyarankan pada tindakan verbal atau fiksi. Tidak semua tingkah laku dapat mencerminkan kedirian tokoh, akan tetapi ada beberapa wujud yang dapat menampilkan reaksi, tanggapan, sifat dan sikap yang dapat mencerminkan kedirian dari tokoh itu sendiri (Nurgiyantoro, 2017:288). Berikut data yang dimaksud untuk menjabarkan tentang tingkah laku dari tokoh Pras.

a) Prasetya Anggara

Pras digambarkan sebagai tokoh yang memiliki dasar tingkah laku yang kasar terhadap seseorang, tetapi tidak semua tingkah laku dari dirinya berwatak kasar. Akan tetapi, data yang didapatkan dari tokoh Pras kebanyakan menunjukkan tentang karakternya yang kasar dan kejam. Data di bawah ini merupakan penjelasan tentang tingkah laku yang dimiliki oleh tokoh Pras.

"Pras mendorong tubuh gadis itu dan dengan segera membuka pintu mobilnya. Ia duduk dibelakang kemudi. Pras segera tancap gas lalu pergi meninggalkan gadis itu." (Malka, 2018:10).

Kutipan di atas menggambarkan tentang tingkah laku dari tokoh Pras yang kasar. Pras mendorong tubuh seorang perempuan yang selalu mengikuti dirinya. Tokoh Pras digambarkan sebagai tokoh yang tidak menyukai wanita murahan yang selalu mengejar dirinya. Melalui perbuatannya dapat tergambar bahwa Pras bersikap kasar terhadap perempuan yang tidak disukainya. Data di atas merupakan kedirian dari tokoh Pras. Semua perempuan yang tidak memikat hatinya, Pras tidak sungkan-sungkan untuk bersikap kasar jika perempuan tersebut mengganggu dirinya. Kalimat "Pras segera tancap gas lalu pergi meninggalkan gadis itu" menjelaskan tentang sikap Pras melalui tingkah lakunya. Selain kasar Pras juga tidak memperdulikan tentang perempuan murahan yang selalu mengikutinya dirinya demi mendapatkan kasih sayang dan cinta dari dirinya. Secara tidak langsung Malka menggambarkan tentang sikap kasar Pras melalui tingkah lakunya. Selain data di atas, ada teks lain yang dapat mencerminkan tentang kedirian dari tokoh Pras. Teks ini merupakan penjabaran dari tingkah laku tokoh Pras itu sendiri. Teks yang dimaksud oleh peneliti adalah sebagai berikut.

"Pras mengusap rahangnya berkali-kali. Berjalan mondarmandir tanpa tahu arah dantujuan. Kali ini ia benar-benar frustasi. Ia 
merasa tersudut dengan pilihan yang diberikan sang papa." (Malka, 2018:21).

Data di atas menggambarkan tentang sikap frustrasi dari tokoh Pras melalui tingkah lakunya. Pras digambarkan sebagai tokoh yang sedang memiliki banyak masalah dan sedang frustrasi. Perbuatan yang sedang mengusap rahangnya menggambarkan tentang sikap Pras yang sedang pasrah terhadap pilihan yang sedang diberikan oleh orang tuanya. Pras saat ini digambarkan sebagai tokoh yang pasrah dalam menentukan jalan hidupnya. Potongan kalimat "Berjalan mondar-mandir" menjelaskan tentang tingkah laku Pras kepada pembaca melalui sikap kebingungannya. Secara tidak langsung, pengarang menggambarkan tentang sikap pasrah dan kebingungan yang dimiliki oleh tokoh Pras.

b) Adara Prasetya

Adara menampilkan tingkah laku yang dapat mencerminkan kedirian tokohnya sendiri. Data di bawah ini merupakan penjabaran tentang tokoh Adara melalui teknik pelukisan tingkah laku.

"Adara melangkah masuk kedalam kamar. Ia duduk terdiam di tepi tempat tidur. Pandangannya menerawang. Adara tahu, penolakan akan ia terima. Dalam hati hanya doa yang ia panjatkan pada sang kuasa untuk memberinya ketabahan. (Malka, 2018:41-41).

Kutipan di atas menggambarkan tentang kedirian dari tokoh Adara melalui sikap sabarnya. Sikap yang digambarkan terhadap tokoh Adara melalui teknik ini pembaca dapat mengetahui bahwa Adara memiliki sikap sabar. Demi tidak memanjangkan permasalahan dengan suaminya, Adara memilih untuk pergi dihadapan Pras. Kalimat "ia duduk terdian di tepi tempat tidur" menjelaskan bahwa Adara lebih memilih diam terhadap semua perkataan dan ejekan suami terhadapnya. Sebagai wanita yang memiliki ilmu agama, lumrahnya sebagai perempuan digambarkan dengan tokoh yang lemah. Setiap perkataan atau perbuatan yang bisa menyayat hatinya, Adara tidak pernah membalas perkataan suaminya dengan bahasa yang kasar. Adara tetap menerima dan bersabar terhadap sikap dan kelakuan suami terhadap dirinya. Sebagai perempuan yang sudah menjadi seorang istri, terlebih tokoh Adara digambarkan sebagai tokoh yang baik dan sangat banyak data yang dilukiskan terhadapnya tentang hal-hal kebaikan. Data selanjutnya adalah kutipan yang dapat menggambarkan tentang keikhlasan Adara dalam menghadapi tingkah suaminya. Data yang dimaksud adalah sebagai berikut.

"Lo taruh tas gue di kamar, dan lo buatin gue kopi sekarang," perintah Pras pada Adara.

Adara mengangguk dan berjalan kedapur.

Adara mengusap dadanya berkalikali di ikuti doa ta'awudz. Suaminya menyuruh

Adara seolah-olah
menyamakannya dengan
pembantu. Tapi adara selalu mau
membuatkan kopi untuk sang
suami." (Malka, 2018:68).

Kutipan di atas menjelaskan tentang sikap Adara yang sabar dan ikhlas terhadap tingkah suaminya. Walaupun Adara merasa seolah-olah dirinya disamakan sebagai seorang pembantu, namun dengan hati ikhlas Adara selalu melakukan terhadap suruhan suaminya. Kalimat "Tapi adara selalu mau membuatkan kopi untuk sang suami" menjelaskan tentang tingkah laku Adara. Adara tidak pernah bosan membuatkan kopi untuk suaminya yang baru pulang dari kantor. Walaupun Pras terkesan cuek di hadapannya, Pras tetap menyukai kopi buatan dirinya sehingga menjadi alasan untuk ikhlas dan bahagia bagi Adara. Bagaimanapun juga 
sang suami menyukai terhadap minuman yang selalu disediakannya, bahkan sudah menjadi kecanduan sehingga setiap pulang kerja selalu menanyakan kopi buatannya. Dari data di atas terlihat bahwa Adara memiliki sikap yang ikhlas dalam menghadapi suami melalui tingkahnya.

\section{Teknik Pikiran dan Perasaan}

Teknik pikiran dan perasaan dapat dilihat melalui kata-kata, tingkah laku, sikap dan pandangan pelaku. Perbuatan dan kata-kata merupakan perwujudan konkret dari tingkah laku pikiran dan perasaan. Oleh karena itu, dalam tingkah laku secara fisik dan verbal orang-orang tentu dapat berpura-pura dan berlaku secara tidak sesuai dengan yang ada dalam pikiran dan hatinya. Namun, seseorang tidak memungkinkan untuk dapat berlaku pura-pura terhadap pikiran dan perasaan dari hatinya sendiri (Nurgiyantoro, 2017:289).

a) Prasetya Anggara

Malka menggambarkan tokoh Pras melalui teknik pikiran dan perasaan. Teknik pikiran dan perasaan ini adalah pelukisan seorang tokoh melalui pikiran dan perasaan yang dapat menggambarkan kedirian dari tokoh itu sendiri. Di bawah ini terdapat data yang menjelaskan tentang penyampaian pikiran dan perasaan dari tokoh Pras. Data yang di maksud adalah sebagai berikut.

"Menurutnya Dara adalah gadis misterius. Nama yang selama ini membayangi setiap langkahnya. Bayangan gadis itu selalu menghantui pikirannya, seolaholah ada magnet kuat yang tak bisa mengalihkan pandangannya pada gadis lain, secantik apapun." (Malka, 2018:11).

Data dari kutipan di atas terlihat kedirian dari tokoh Pras dengan menggunakan teknik pikiran dan perasaan. Pras digambarkan sebagai tokoh yang terlihat kebingungan akibat kehilangan sosok Dara gadis impiannya yang selama ini dicintainya. Kalimat "Menurutnya Dara adalah gadis misterius. Nama yang selama ini membayangi setiap langkahnya" menjelaskan bahwa Pras kebingungan saat mengingat tentang gadis tersebut. Semua cara telah ia lakukan demi mendapatkan kabar tentang keberadaan perempuan yang tiba-tiba menghilang dari kehidupannya. Akan tetapi, tidak ada orang yang bisa memberikan tentang jejak dimana gadis tersebut berada. Penggalan kalimat selanjutnya "Bayangan gadis itu selalu menghantui pikirannya, seolaholah ada magnet kuat yang tak bisa mengalihkan pandangannya pada gadis lain" menjelaskan bahwa Pras benarbenar kebingungan memikirkan tentang keberadaan Dara. Sehingga Pras merasa terhipnotis dan tidak pernah bisa menyukai gadis lain selain Dara. Melalui pikiran dan perasaan dari tokoh Pras secara tidak langsung pembaca akan mengetahui tentang sikapnya yang terlihat kebingungan. Selanjutnya, ada data lain yang dapat melukiskan kedirian dari tokoh Pras melalui pemikirannya.

Pras juga digambarkan sebagai tokoh yang harus bersikap optimis oleh pengarang. Berikut data yang dapat menjelaskan tentang gambaran yang dapat melukiskan kediriannya.

"Beberapa kali Pras menyisir rambutnya dengan jari. Walaupun begitu, otaknya mulai berpikir. Bagaimanapun juga, Pras menikmati profesinya sebagai wakil Presdir dan ia tidak mau kehilangan itu semua. Semua kekayaan papanya harus jatuh ke tangannya." (Malka, 2018:19).

Kutipan di atas menjelaskan tentang pemikiran Pras. Malka menjelaskan tentang Pras yang sedang berpikir tentang kebaikan dalam hidupnya. Bagaimanapun caranya setiap keputusan dari orangtuanya jangan langsung ia terima dan harus dipikirkan beberapa kali untuk melakukannya. Kalimat "Bagaimanapun juga, Pras menikmati profesinya sebagai wakil Presdir dan ia tidak mau kehilangan 
itu sетиа" menjelakan tentang pemikiran Pras yang tidak boleh tergesa-gesa dalam memutuskan tindakan ancaman dari orang tuanya.Tokoh Pras digambarkan sebagai tokoh yang tidak tergesa-gesa dalam menyelesaikan semua masalah. Pras akan kehilangan harta warisan jika tidak menuruti permintaan kedua orangtuanya untuk menikah. Dari kalimat "Sетиa kekayaan papanya harus jatuh ke tangannya" menjelaskan tentang pemikiran yang optimis dari tokoh Pras bagaimanapun caranya harta sang Papa harus jatuh ke tangannya.

b) Adara Prasetya

Pikiran dan perasaan merupakan suatu hal yang dapat mencerminkan kedirian seorang tokoh dalam sebuah novel. Sama halnya dengan tokoh Pras, tokoh Adara juga digambarkan kediriannya melalui teknik pikiran dan perasaan. Data untuk menjabarkan tentang tokoh Adara melalui teknik pikiran dan perasaan adalah sebagai berikut.

"...Adara tak pernah tahu
bagaimana akhirnya cerita
pernikahannya. Ikhlas dan
tawakkal adalah pilihannya saat
ini. Hanya dalam hati ia sudah
berjanji pada dirinya sendiri;
sebelum sang suami menerima
dirinya apa adanya, ia tak akan
membuka cadar di depan
suaminya. (Malka, 2018:42).

Keseluruhan kutipan di atas menggambarkan tentang sikap ikhlas dari tokoh Adara melalui pemikirannya. Kalimat "Ikhlas dan tawakkal adalah pilihannya saat ini" menjelaskan tentang sikap dari tokoh Adara. Adara digambarkan oleh Malka dengan kehidupan yang ikhlas dalam menerima setiap cobaan hidupnya. Akan tetapi selain ikhlas Adara juga digambarkan dengan sikap ketegasan yang melekat pada dirinya. sikap tegasnya terlihat dari kutipan kalimat "Hanya dalam hati ia sudah berjanji pada dirinya sendiri; sebelum sang suami menerima dirinya apa adanya, ia tak akan membuka cadar di depan suaminya" menggambarkan tentang kedirian Adara. Adara digambarkan dengan sikap tegas bahwa tidak mau membuka cadar di depan suaminya. Keputusan yang telah di tetapkannya tidak akan berubah, dikarenakan ada suatu hal yang digambarkan terhadapnya oleh pengarang pada bab sebelumnya. Malka melukiskan tokoh Adara yang memiliki aib di masa gadisnya sehingga ia merubah penampilan wujudnya dengan memakai cadar.

Adara juga digambarkan melalui data lain untuk melukiskan kedirian dari dirinya. Data dibawah ini menjelaskan tentang kebahagiaan Adara melalui pikirannya yang masih dalam proses perencanaan. Data yang dimaksud adalah sebagai berikut.

“... kali ini ia berencana masak deng deng sapi sama kari ayam, ditambah sayur sop. Dalam hatinya terasa damai karena sang suami menyukai masakannya. (Malka, 2018:91).

Potongan kutipan di atas menggambarkan tentang kebahagian dari Adara. Selain digambarkan dengan tokoh yang memiliki perwatakan lemah dan sering larut dalam kesedihan, Malka juga tidak lupa memasukkan sikap bahagia kepada tokoh Adara. Melalui pemikirannya, walaupun masih dalam tahap perencanaan untuk membuat masakan kepada suaminya menggambarkan kebahagian dari dirinya.

4. Teknik Arus Kesadaran

Teknik arus kesadaran lebih menekankan pada monolog batin yang ada dalam diri tokoh. Monolog batin adalah ungkapan perasaan tokoh yang disampaikan melalui kedirian tokoh tersebut. Biasanya monolog batin disampaikan dengan memiringkan kalimat yang dimaksud sebagai kedirian dari tokoh yang bersangkutan.

a) Prasetya Anggara 
Monolog batin yang dilakukan oleh tokoh Prasdapat mencerminkan tentang kediriannya sendiri. Data yang dimaksud adalah sebagai berikut.

"Senyum itu mengembang dalam balutan kain panjangnya. Wajah bak bidadari yang menjelma sebagai istri mengalihkan akalnya. Mengingatnya. Yah, Pras mengingat senyum dengan deretam gigi mungil itu saat tersenyum padanya di pagi hari dengan secangkir kopi yang ia seduh dan berikan padanya." (Malka, 2018:467).

Kutipan di atas merupakan monolog batin dari Pras. Monolog batin di atas digunakan sebagai data untuk menganalisis teknik arus kesadaran. Walaupun data tersebut menggambarkan tentang tokoh Adara, tetap saja yang berbicara adalah pikiran dari Pras sendiri. Melalui teknik ini Malka melukiskan tokoh Pras yang sedang mencari kehilangan sosok istrinya. Saat melihat wanita lain yang memakai cadar, Pras berpikir wanita tersebut adalah istrinya akibat pengaruh minuman beralkohol yang merasuki tubuhnya. Pada Teknik ini Malka menggambarkan tokoh Pras yang setengah sadar akibat pemikirannya yang sedang putus asa dalam mencari seorang perempuan yang diinginkannya. Selain kutipan di atas, kutipan di bawah ini juga menggambarkan tentang kedirian dari Pras melalui Teknik arus kesadaran. Data yang yang dimaksud adalah sebagai berikut.

\section{"Bisa jadi kemarin itu Adara, anak yang ia gendong mungkin Agra, lalu anak perempuan itu...? "apa anak perempuan itu anak kandung Adara, dan disini anak perempuan itu bersama ayah biologisnya? Tapi nggak mungkin Adara menyembunyikannya dariku." (Malka, 2018:474).}

Data tentang monolog batin di atas juga melukiskan tentang kedirian dari tokoh
Pras. Monolog tersebut Pras ungkapkan dengan perasaan kebingungan yang masih bertanya dalam hatinya. Pertanyaan "Bisa jadi kemarin itu Adara, anak yang ia gendong mungkin Agra, lalu anak perempuan itu...?" menjelaskan tentang seorang perempuan yang dipikirkan oleh Pras. Pras memikirkan istrinya yang sedikit berbeda dengan kebiasaan Adara membuat hatinya frustasi dan bertanyatanya. pertanyaan selanjutnya "apa anak perempuan itu anak kandung Adara, dan disini anak perempuan itu bersama ayah biologisnya" menjelaskan tentang banyaknya pertanyaan yang timbul dalam benak Pras, sehingga kepercayaannya terhadap istri dipertaruhkan.

b) Adara Prasetya

Malka menggambarkan monolog batin dari tokoh Adara untuk menggambarkan bagaimana kedirian dari Adara sendiri. Data yang dimaksud adalah sebagai berikut.

"seperti keputusanku sudah bulat, Mas. Aku harus pergi dan menghindari semua fitnah ini. Ikatan kita ternyata belum kuat. Tapi aku juga tidak akan tergesagesa. Aku juga harus meminta saran dari teman-temanku." (Malka, 2018:503).

Data di atas terlihat melalui monolog batin dari tokoh Adara yang dapat menggambarkan tentang kediriannya. Monolog tersebut menggambarkan tentang emosi Adara terhadap masalah yang tidak pernah berhenti menghampirinya. Adara memilih untuk sementara waktu menghilang dari kehidupan Pras demi keluarganya. Kalimat "ikatan kita ternyata belum kuat" menjelaskan tentang banyaknya persoalan hidup yang kehadirannya semata untuk memisahkannya dengan sang suami. Akan tetapi, pada kalimat selanjutnya "Tapi aku juga tidak akan tergesa-gesa” Malka juga menjelaskan tentang kecerdikan yang dimiliki oleh Adara dalam menghadapi setiap masalah dan pandai dalam 
mengatasinya supaya tidak tergesa-gesa. Selain data di atas, data di bawah ini juga menggambarkan tentang monolog batin dari tokoh Adara. Data yang dimaksud adalah sebagai berikut.

"andai mas tahu aku ini Dara yang pernah Mas suka, masihkah Mas mau menerimaku? Apakah Mas malah akan semakin membenciku? Asal Mas tahu, aku mulai menyukai Mas, tapi sungguh cintaku pada Allah mengalahkan semua rasaku, ke Mas." lirihnya (Malka, 2018:109).

Kutipan di atas merupakan pertanyaan monolog batin yang timbul dari tokoh Adara. Kutipan tersebut dapat menggambarkan tentang kediriannya yang masih terlihat kebingungan untuk menjelaskan kepada Pras. Adara takut untuk menjelaskan bahwa dirinya adalah seorang perempuan yang pernah Pras ungkapkan cintanya dulu. Melalui kutipan tersebut pembaca dapat mengetahui tentang kebingungan yang dimiliki tokoh Adara dengan bermonolog batin. Selain itu, Malka juga menjelaskan bahwa penyebab kebingungan Adara dikarenakan dia tidak sanggup untuk kehilangan Pras karena Adara sudah mulai menyukainya. Akan tetapi, karena Adara digambarkan sebagai perempuan yang kukuh imannya terhadap agama, walaupun cinta dan kasih sayangnya terhadap Pras mulai tumbuh tetapi tidak ada yang bisa menandingi cintanya terhadap sang pencipta.

5. Teknik Reaksi Tokoh

Teknik reaksi tokoh ini dilihat melalui reaksi seorang tokoh terhadap suatu kejadian, masalah, keadaan, kata, sikap tingkah laku orang lain dan sebagainya yang berupa "rangsangan" dari luar diri tokoh yang bersangkutan.

a) Prasetya Anggara

Reaksi dari Pras terhadap suatu kejadian dapat mencerminkan kedirian dari tokoh Pras itu sendiri. Namun, tidak semua reaksi yang dilakukan oleh Pras dapat mencerminkan kediriannya sendiri. Berikut ini data yang dimaksud untuk menggambarkan tentang reaksi dari tokoh Pras.

"Jantung Pras berdegup kencang, tapi ia tepis. Ia tidak mau jatuh cinta pada gadis yang bercadar. Terlihat aneh menurutnya." (Malka, 2018:27).

Kutipan teks di atas menjelaskan tentang bagaimana reaksi Pras saat menatap bola mata Adara. Kalimat "jantung Pras berdegup kencang" menjelaskan tentang reaksi yang timbul dari dirinya dan dapat dijadikan sebagai acuan tentang penokohan dari tokoh Pras. Kedirian yang dapat dilihat ialah kedirian Pras yang digambarkan sebagai tokoh yang sedang kagum melihat kecantikan istrinya. Namun, pada kalimat "Ia tidak mau jatuh cinta pada gadis yang bercadar" menggambarkan juga tentang reaksinya yang tidak membiarkan perasaannya menyukai terhadap Adara. Malka menggambarkan reaksi dari tokoh Pras yang terlihat kagum terhadap Adara namun sengaja tidak diperlihatkan karena Pras tidak mau jatuh cinta pada wanita bercadar. Selain data di atas, data di bawah ini juga bisa menunjukkan tentang reaksi dari tokoh Pras. Melalui percakapan dengan orang tuanya dapat terlihat tentang reaksi dari dirinya. Data yang dimaksud adalah sebagai berikut.

"Pa! Ma!" panggil Pras dari luar pintu kamar.

"Masuk!"

Pras membuka pintu. Andi memasang wajah datar pada putra semata wayangnya itu. "Sudah kamu putuskan?"

Pras mengangguk. "Aku mau menikah dengan pilihan Papa dan Mama," ujar Pras dengan nada lemah." (Malka, 2018:19-20).

Percakapan di atas dapat menggambarkan tentang bagaimana reaksi Pras terhadap orangtuanya. Keputusan yang diberikan oleh orangtua membuat Pras sangat berat 
untuk menerimanya. Pras dijodohkan dengan Adara oleh orang tuanya, keputusan tersebut harus Pras terima. Jika Pras tidak mau menerima perjodohan tersebut, maka Pras tidak akan mendapatkan harta warisan dari orangtuanya. Ucapan "Aku mau menikah dengan pilihan Papa dan Mama" menjelaskan tentang reaksi dari tokoh Pras yang terlihat lemah dan pasrah di depan orangtuanya. Walaupun terasa berat namun Pras tetap harus melakukannya dan pasrah terhadap semua kejadian demi harta warisan.

b) Adara Prasetya

Data yang dimaksud melalui

teknik reaksi tokoh terhadap tokoh Adara adalah sebagai berikut.

"Adara mempercepat langkahnya dan memilih untuk tidak berdebat dengan laki-laki yang pernah menyatakan perasaan padanya di atas jembatan beberapa tahun lalu itu." (Malka, 2018:51).

Kutipan di atas menggambarkan tentang reaksi dari tokoh Adara. Tingkah laku yang dilakukan seorang tokoh dapat menggambarkan tentang reaksi dari tokoh itu sendiri. Potongan kalimat "Adara mempercepat langkahnya dan memilih untuk tidak berdebat..." menjelaskan tentang reaksi dari tokoh Adara. Adara adalah tokoh yang sering digambarkan dengan perwatatakan yang sabar. Setiap perkataan yang ia ungkapkan tidak lagi bermakna, maka Adara memilih pergi dan tidak ingin berdebat demi tidak memperpanjang masalah. Secara tidak langsung pembaca dapat mengetahui tentang reaksi yang dilukiskan terhadap Adara oleh pengarang. Malka melukiskan tokoh Adara yang tidak ingin berdebat dan mengalah dalam setiap permasalahan. Selain data di atas, di bawah ini juga mempunyai data untuk mengetahui tentang reaksi dari tokoh Adara. Data yang dimaksud adalah sebagai berikut.

"Adara memejamkan mata sejenak. Ia memegang dada dari balik hijab panjangnya sambil membaca $t a$ 'awudz. Adara menghela nafas sejenak.

Mengatur degup jantung yang juga dijalari emosi itu. Ia mencoba tak terpancing amarah." (Malka, 2018:79).

Paragraf di atas Malka melukiskan kedirian tokoh Adara melalui reaksi dari dirinya. Kalimat "Adara menghela nafas sejenak" menggambarkan tentang reaksi dari Adara yang sedang menahan kepedihan. Adara digambarkan sebagai tokoh yang tidak secara langsung membalas setiap perkataan orang yang menyakitinya. Kalimat selanjutnya "Mengatur degup jantung yang juga dijalari emosi itu" menjelaskan tentang sikap Adara. Adara mengatur keseimbangan sikap kemarahan hatinya agar tidak terlalu cepat terpancing amarah. Walaupun sebagai tokoh yang banyak dilukiskan dengan memiliki sikap kesabaran yang lebih, namun Malka juga menggambarkan tokoh Adara yang memiliki sikap emosi. Akan tetapi, Malka juga tidak lupa melukiskan cara tokoh Adara meredamkan kemarahan melalui reaksi kesabarannya.

6. Teknik Reaksi Tokoh Lain

Teknik reaksi tokoh lain merupakan teknik yang terikat dengan teknik reaksi tokoh sebelumnya. Kedua teknik ini saling berhubungan untuk membangun kedirian dari tokoh dan penokohan dalam novel. Perbedaanya teknik reaksi tokoh menjelaskan tentang satu tokoh, sedangkan teknik reaksi tokoh lain meliputi dua tokoh untuk menentukan salah satu kedirian tokoh tersebut.

a) Prasetya Anggara

Reaksi dari tokoh lain dapat mencerminkan tentang kedirian dari tokoh Pras. Teknik ini menggunakan reaksi dari orang lain untuk melihat kedirian dari tokoh utama. Berikut ini data yang didapatkan untuk menganalisis kedirian dari tokoh Pras . 
"Pak Sunoto bertepuk tangan diikuti yang lain.

"Ide yang luar biasa, Pak Pras!"

puji Pak Hendru salah satu

investor besar yang akan

bekerjasama juga dengan Pras.

"Terima kasih, Pak," ucap Pras

,mengangguk hormat.

"Benar-benar ide cemerlang," sahut yang lainnya. (Malka,

2018:321).

Kutipan di atas merupakan reaksi dari tokoh lain terhadap tokoh Pras. Pras digambarkan sebagai tokoh yang mempunyai keahlian dibidang perusahaan. Ucapan "Ide yang luar biasa, Pak Pras" menjelaskan tentang kecerdasan yang dimiliki oleh Pras. Pujian yang diberikan oleh Pak Hendru dapat memperlihatkan tentang reaksi dari tokoh Pras. Selain digambarkan sebagai orang kaya Pras juga digambarkan sebagai tokoh yang pandai dalam berbisnis.

b) Adara Prasetya

Teknik reaksi dari tokoh lain terhadap tokoh Adara sering digambarkan dengan baik dikarenakan Adara adalah tokoh yang memiliki perwatakan yang baik. Data di bawah ini dapat mencerminkan kedirian dari tokoh Adara melalui reaksi dari tokoh lain.

"Dia gadis yang kuat. Saya

mengenal dia, dia bukan seorang teroris, justru dia wanita solehah dan kalian bisa belajar agama darinya," tunjuk Karsimah pada

Adara. Semuanya kebanyakan

tertunduk. (Malka, 2018:116).

Kutipan teks di atas mendeskripsikan reaksi orang lain terhadap tokoh Adara. Walaupun kutipan di atas bersifat sebagai pendapat seseorang, tetap saja ini reaksi yang digambarkan dari sikap Adara selama ini. Dari awal memang Adara diceritakan sebagai tokoh yang tidak takut dalam menghadapi setiap masalah. Selain kuat, Adara juga digambarkan sebagai wanita saleha yang rajin dalam belajar tentang ilmu agama. Melalui penyampaian kedirian dari tokoh lain terhadap tokoh Adara pembaca dapat mengetahui tentang reaksinya yang dilukiskan oleh pengarang. Selain dari nenek Karsimah, melalui tokoh lain juga terdapat data tentang gambaran yang dilukiskan terhadap tokoh Adara. Data yang didapatkan adalah sebagai berikut.

7. Teknik Pelukisan Latar

Pelukisan latar adalah sebuah teknik yang digunakan pengarang untuk melukiskan kedirian dari seorang tokoh. Keadaan latar tertentu, dapat menimbulkan kesan tertentu terhadap seorang tokoh. Suasana di sekitar tokoh dapat menentukan tentang pelukisan tokoh dari pengarang. Latar suasana dapat menentukan pelukisan tokoh secara tidak langsung dalam sebuah karangan (Nurgiyantoro, 2017:295).

a) Prasetya Anggara

Berikut data yang dilukiskan terhadap tokoh Pras melalui pelukisan latar.

"Malam itu Prasetya dan temantemannya baru pulang dari tempat clubbing. Mereka sudah keluar dari ruangan klub. Salah satu temannya mengikuti dari belakang Pras sampai ke parkiran. Temannya itu mabuk berat dan mengeluarkan semua isi perutnya karena pengaruh minuman beralkohol yang ia minum tadi. (Malka, 2018:7).

Paragraf di atas merupakan gambaran tentang pelukisan latar. Malka menggambarkan latar yang dijadikan sebagai pelukisan kedirian untuk tokoh Pras. Kalimat "Malam itu Prasetya dan teman-temannya baru pulang dari tempat clubbing" menjelaskan tentang kebiasaan Pras. Pras digambarkan sebagai tokoh yang memiliki kebiasaan atau pola hidup yang boros dan sering menghabiskan uang di tempat clubbing. Pras sebagai tokoh yang terlahir dari keluarga kaya, tidak heran jika kelakuannya digambarkan 
seperti data di atas. Melalui data tersebut pembaca dapat mengetahui tentang kedirian Pras sebagai orang kaya, namun memiliki sifat boros yang digunakan untuk hal-hal yang tidak berguna melalui teknik pelukisan latar

b) Adara Prasetya

Data yang di maksud untuk pelukisan latar adalah sebagai berikut.

"kamar yang berukuran luas.

Tema girlishmewarnai aksen

kamarnya. Jendela bingkai ukiran yang indah bermotif bunga senada dengan gorden yang berenda 85 bunga dan bermotif kupu-kupu. Warna peach menjadi warna pilihan yang mendominasi kamarnya. (Malka, 2018:94).

Berdasarkan data tersebut, pelukisan latar yang digunakan oleh pengarang untuk menghadirkan tokoh Adara berdasarkan kreatifnya dalam memilih tema tentang warna kamar. Adara sering digambarkan sebagai tokoh yang menyukai tentang keunikan, baik tentang keadaan di dalam kamarnya maupun tentang keunikan rumahnya. Kalimat "Jendela bingkai ukiran yang indah bermotif bunga senada dengan gorden yang berenda bunga dan bermotif kupu-kupu" menjelaskan tentang kedirian dari tokoh Adara. Adara sangat kreatif dalam memilih suatu pilihan yang senada agar terlihat indah saat dipandang. Malka melukiskan tentang kedirian dari tokoh Adara yang menyukai warna cerah tetapi terlihat natural.

8. Teknik Pelukisan Fisik

Sama halnya dengan latar, pelukisan wujud fisik tokoh berfungsi untuk lebih mengintensifkan sifat kedirian tokoh. Pelukisan keadaan fisik tokoh dalam kaitannya dengan penokohan terkadang memang terasa penting Sebuah novel, di dalamnya keadaan fisik tokoh perlu dilukiskan terutama jika ia memiliki betuk fisik yang khas sehingga pembaca dapat menggambarkan secara imajinatif. memang tidak semua novel terdapat tentang teknik pelukisan fisik ini, tetapi ada juga beberapa novel yang melukiskan tentang bentuk fisik untuk melihat kedirian dari tokoh yang ada dalam novel tersebut (Nurgiyantoro, 2017:296).

a) Prasetya Anggara

Fisik dari seseorang tokoh dapat menggambarkan tentang kedirian dari tokoh itu sendiri. Melalui teknik pelukisan fisik yang digambarkan oleh Malka, pembaca dapat mengetahui tentang keadaan fisik dari tokoh Pras. Data yang dimaksud adalah sebagai berikut.

"Prasetya Anggara terlihat gagah dan tampan dengan setelan kemeja berwarna biru dan celana denim hitamnya. Tubuh tinggi dengan warna kulit terang menambah kesempurnaan penampilan fisiknya." (Malka, 2018:8).

Keseluruhan teks di atas menggambarkan kedirian tokoh dari tokoh Pras. Kalimat "Prasetya Anggara terlihat gagah dan tampan dengan setelan kemeja berwarna biru dan celana denim hitamnya" menggambarkan kedirian tokoh Pras tentang pelukisan fisik. Tokoh Pras digambarkan sebagai tokoh yang terlihat gagah dan tampan. Selain itu untuk menambah kesempurnaan dari segi fisiknya, Malka melukiskan tokoh Pras yang memiliki tubuh tinggi dan memiliki warna kulit terang untuk menambah daya tarik dari pembaca. Malka menggambarkan tokoh Pras yang terlihat tampan melalui kutipan di atas sehingga secara pembaca dapat mengetahui tentang penampilan fisiknya. Teknik ini digunakan untuk mempermudah pembaca dalam memahami kedirian tokoh Pras melalui pelukisan fisik.

b) Adara Prasetya

Bentuk fisik merupakan ciri khas yang dimiliki oleh tokoh tersebut. Malka juga tidak lupa menggambarkan kedirian tokoh Adara melalui teknik pelukisan fisik. Data yang menjadi teknik pelukisan fisik terhadap Adara adalah sebagai berikut. 
"Dari ujung meja nomor sebelas duduk seorang gadis berkulit putih tengah menikmati minumannya di atas meja. Dialah Dara-gadis rupawan-idaman setiap pemuda." (Malka, 2018:55).

Data di atas merupakan gambaran pelukisan fisik dari tokoh Adara. Adara digambarkan sebagai tokoh yang mempunyai ciri khas atau bentuk fisiknya tersendiri. Potongan kalimat "seorang gadis yang berkulit putih" menjelaskan tentang fisik dari tokoh Adara. Melalui kutipan dari bentuk fisik di atas pembaca dapat mengetahui tentang gambaran yang dilukiskan oleh pengarang terhadap tokoh Adara sebagai orang yang bersih dan suci. Adara dilukiskan sebagai tokoh yang masih gadis dan berkulit putih menandakan tentang kecantikan yang ia miliki.

9. Teknik Catatan Tentang Identifikasi Tokoh

Pada teknik ini data yang didapatkan ada dua untuk dianalisis menjadi satu hasil peneliti. Teknik cakapan tentang identifikasi tokoh yang didapatkan ialah teknik melalui prinsip pengulangan. Data yang didapatkan adalah sebagai berikut.
"Menurutnya, Dara adalah gadis misterius. Nama yang selama ini membayangi langkahnya. Semua pengawal ia tugaskan mencari gadis itu. Namun hasilnya nihil." (Malka, 2018:11).

"Pras semakin mendesah dengan napas tercekat. Bagi Pras, adara adalah wanita yang penuh tekateki. Namun ia acuhkan semua isi pikirannya. Pras menginggkari setiap benih rasa yang mulai tertancap di hatinya." (Malka, 2018:167).

Kutipan dari data di atas, Malka menjelaskan tentang kedirian dari tokoh Pras. Pras dilukiskan dengan kedirian yang masih kebingungan terhadap tokoh Adara. Hal ini hadirnya tokoh Pras dengan penggambaran dan pelukisan ciri kedirian yang melekat pada dirinya dapat dilihat melalui data di atas. Walaupun datanya berbeda, secara keseluruhanmaksudnya hampir sama yaitu tentang sikap kebingungan yang timbul dari tokoh Pras terhadap tokoh Adara. Malka menghadirkan data tersebut secara berulang-ulang untuk mempertegas ciri kedirian dari tokoh Pras kepada pembaca agar tidak terjadi kesalahan penafsiran.

Tabel 1. Data Teknik Pelukisan Langsung dan Teknik Pelukisan Tidak Langsung

\begin{tabular}{|c|c|c|c|}
\hline No & $\begin{array}{l}\text { Teknik } \\
\text { Pelukisan } \\
\text { Tokoh }\end{array}$ & $\begin{array}{l}\text { Tokoh } \\
\text { Utama }\end{array}$ & Kutipan \\
\hline \multirow[t]{4}{*}{1} & \multirow{4}{*}{$\begin{array}{l}\text { Pelukisan } \\
\text { Tokoh } \\
\text { Langsung }\end{array}$} & \multirow[t]{4}{*}{ Pras } & $\begin{array}{l}\text { "Pemuda angkuh itu masuk kedalam mobil. Duduk sambil } \\
\text { melipat lengannya. Satu kancing teratasnya ia buka. } \\
\text { Rambut yang basah ia sisir dengan jari." (Malka, 2018:8). }\end{array}$ \\
\hline & & & $\begin{array}{l}\text { "Pras yang sendirian menggepalkan tangannya. Ia } \\
\text { mencoba untuk menenangkan degup jantungnya yang } \\
\text { berdetak cepat karena emosi." (Malka, 2018:19). }\end{array}$ \\
\hline & & & $\begin{array}{l}\text { "iya, Neng. Warga di sini menyangka keluarga ini bagian } \\
\text { dari teroris. } \\
\text { Seketika Pras langsung berdiri, ia tak terima. Pras mulai } \\
\text { terselut emosi dan naik pitam. Raut wajahnya merah } \\
\text { padam." (Malka, 2018:71). }\end{array}$ \\
\hline & & & $\begin{array}{l}\text { "Pras duduk menghadap jendela luar kamar. Rahangnya } \\
\text { gemerutuk, tangannya terkepal. Raut wajahnya memerah } \\
\text { menandakan ia sedang menahan amarah." (Malka, } \\
\text { 2018:78). }\end{array}$ \\
\hline
\end{tabular}




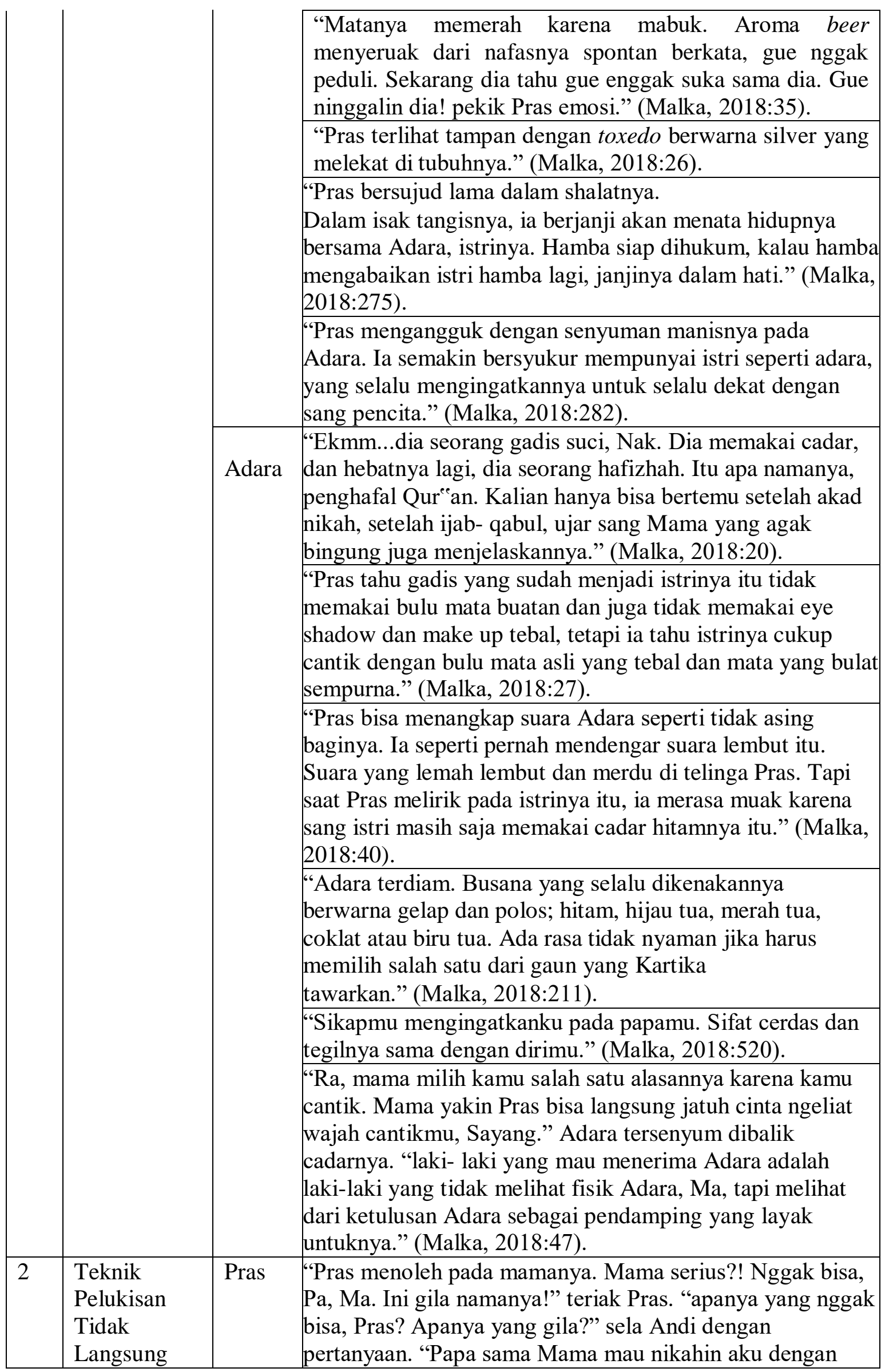




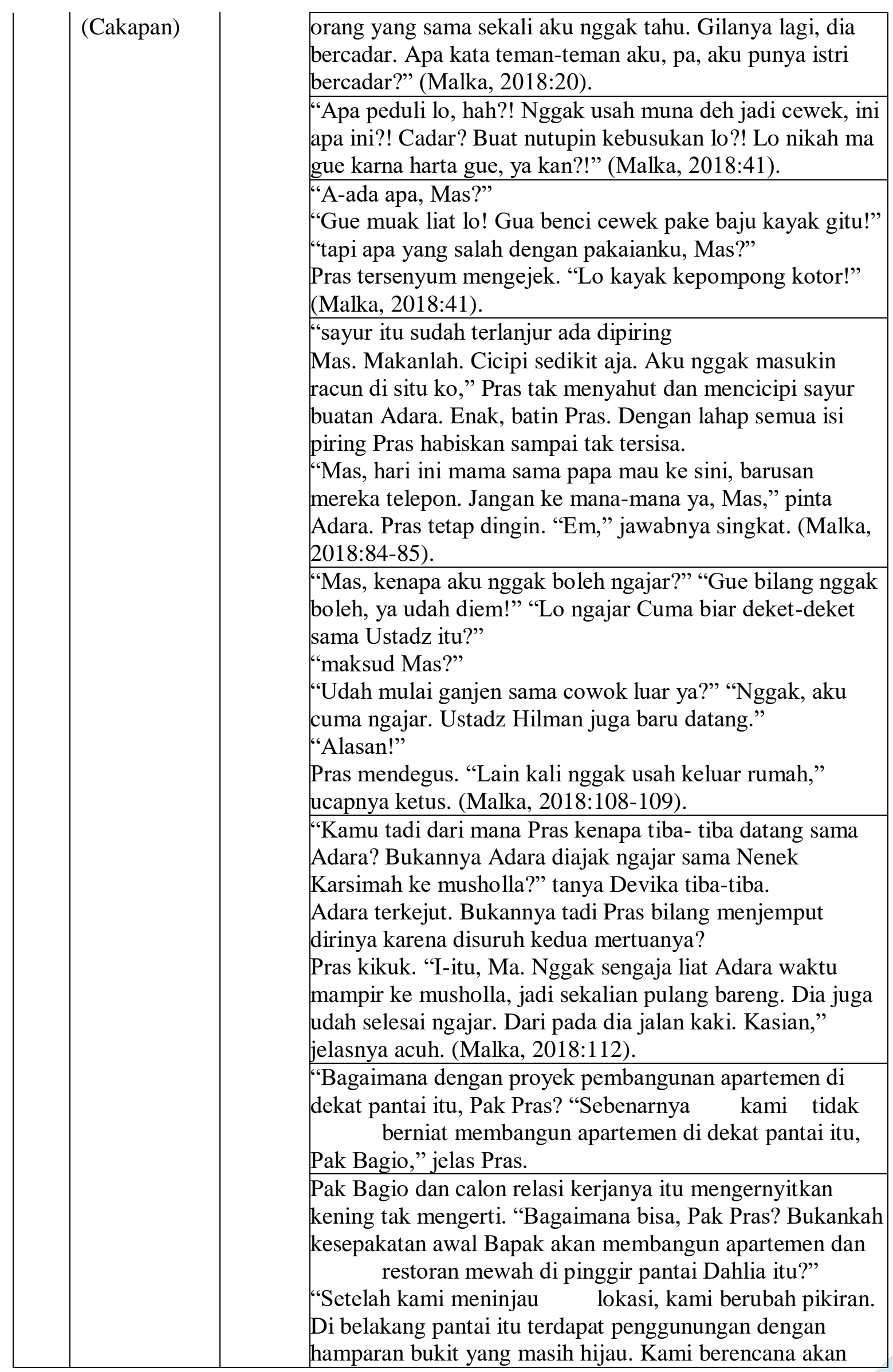




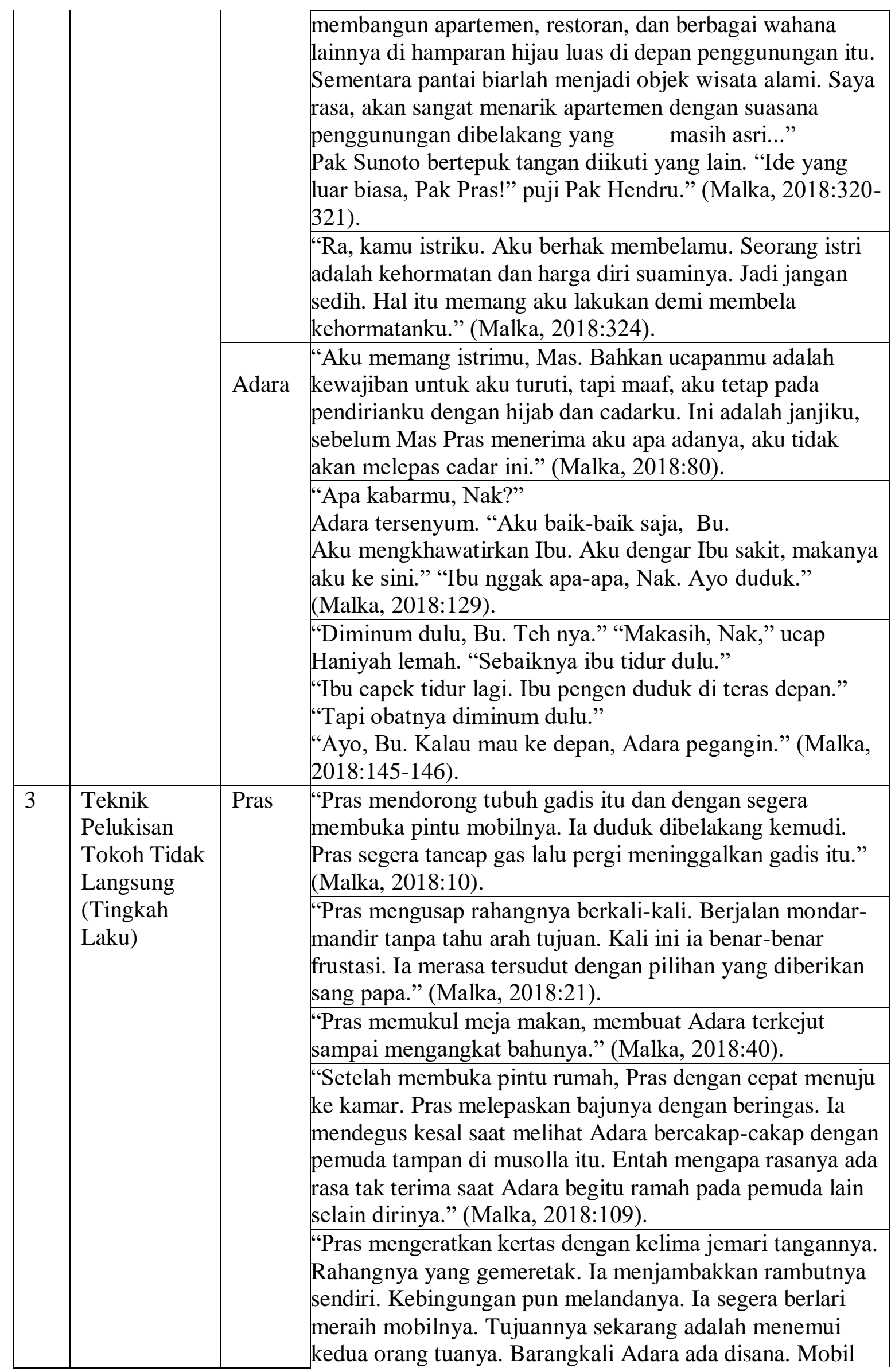




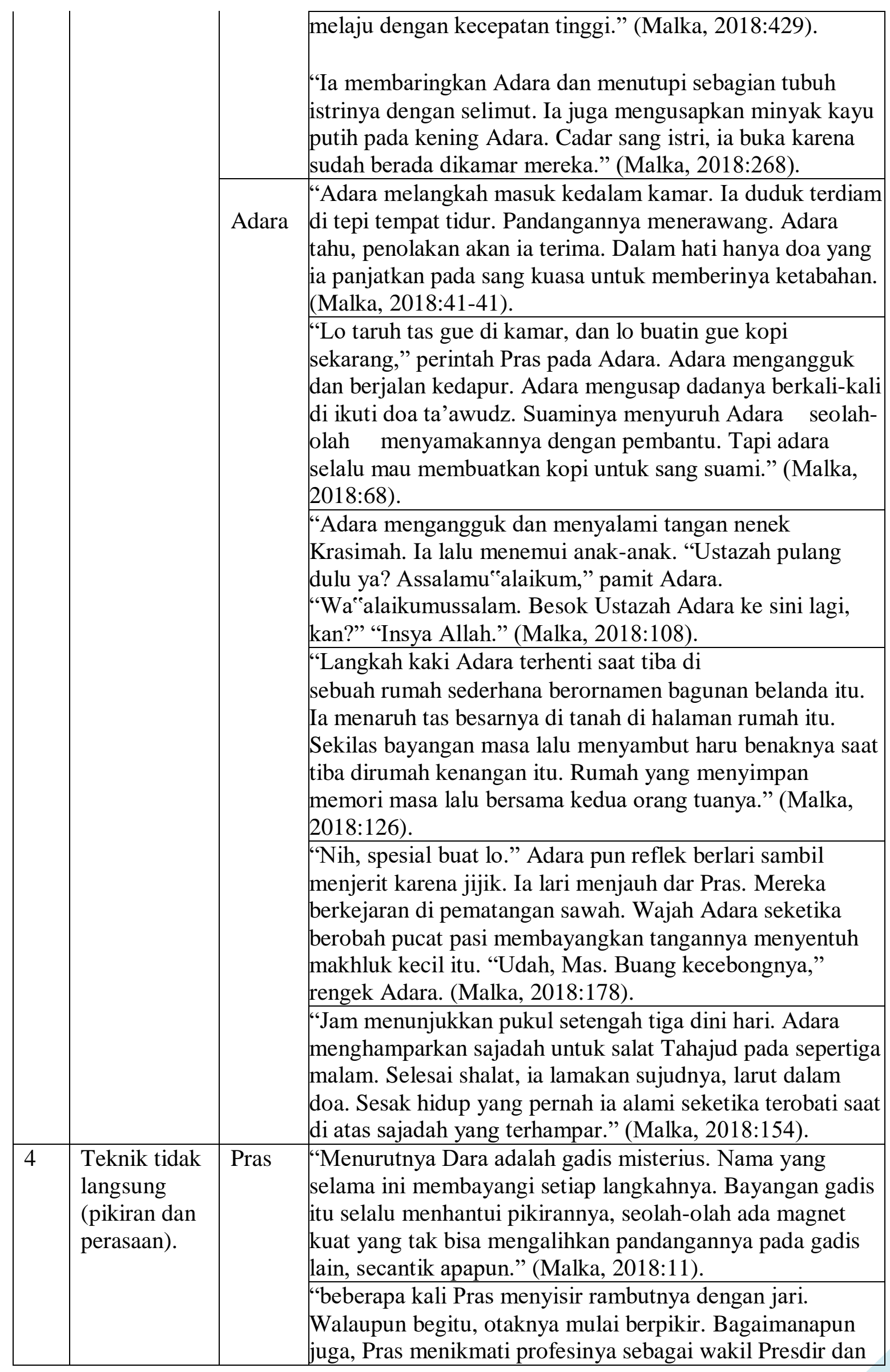




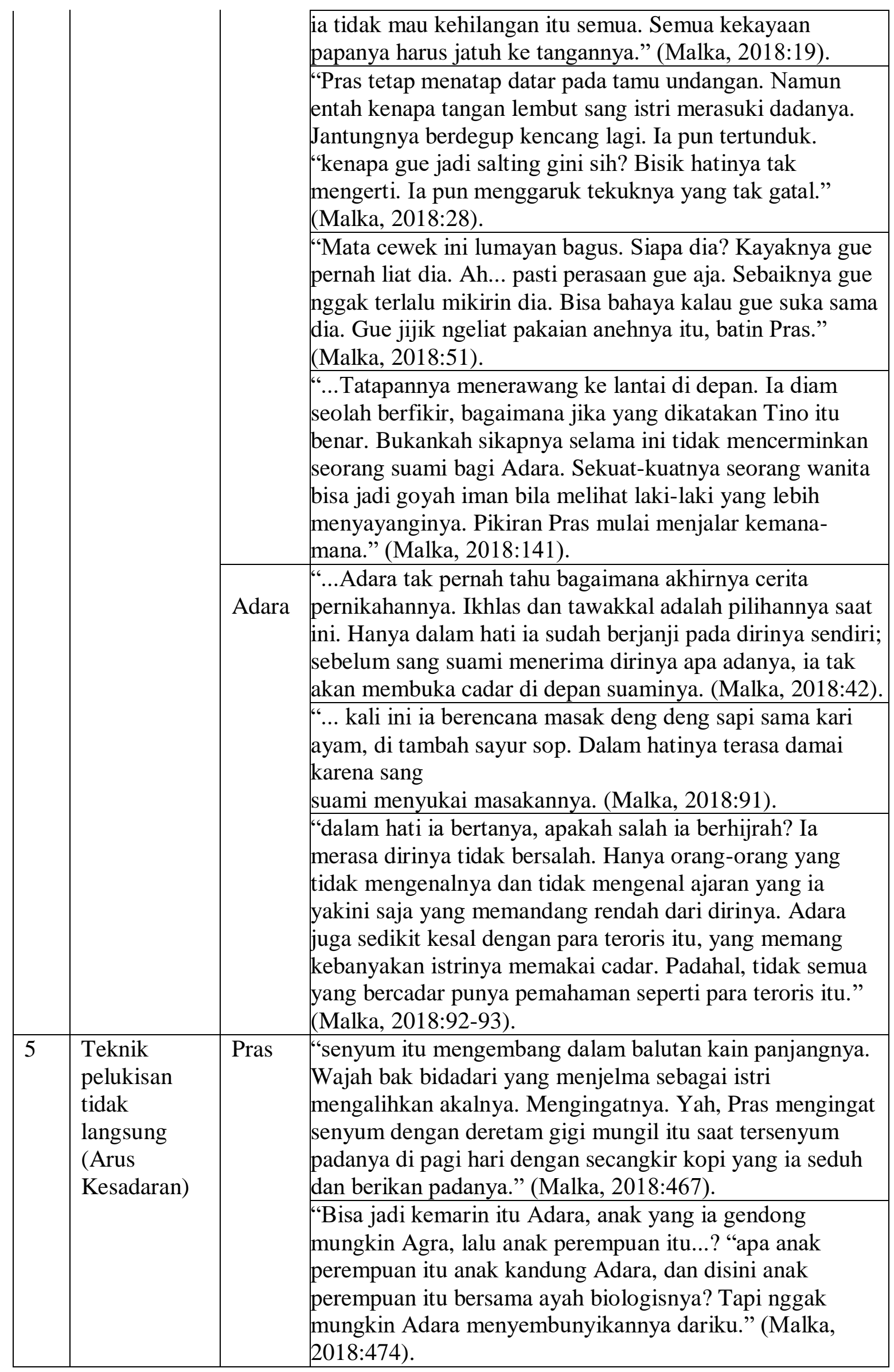




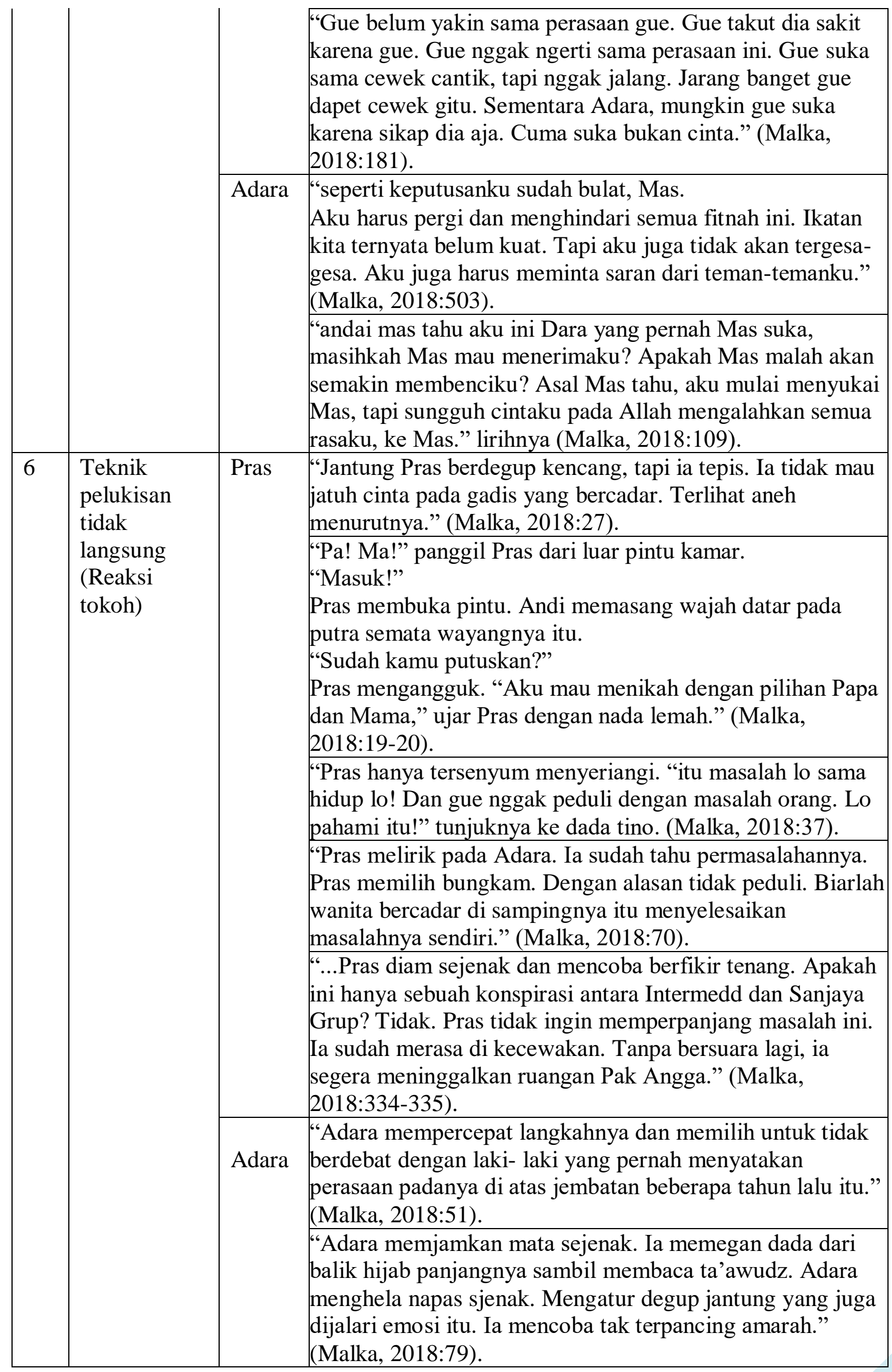




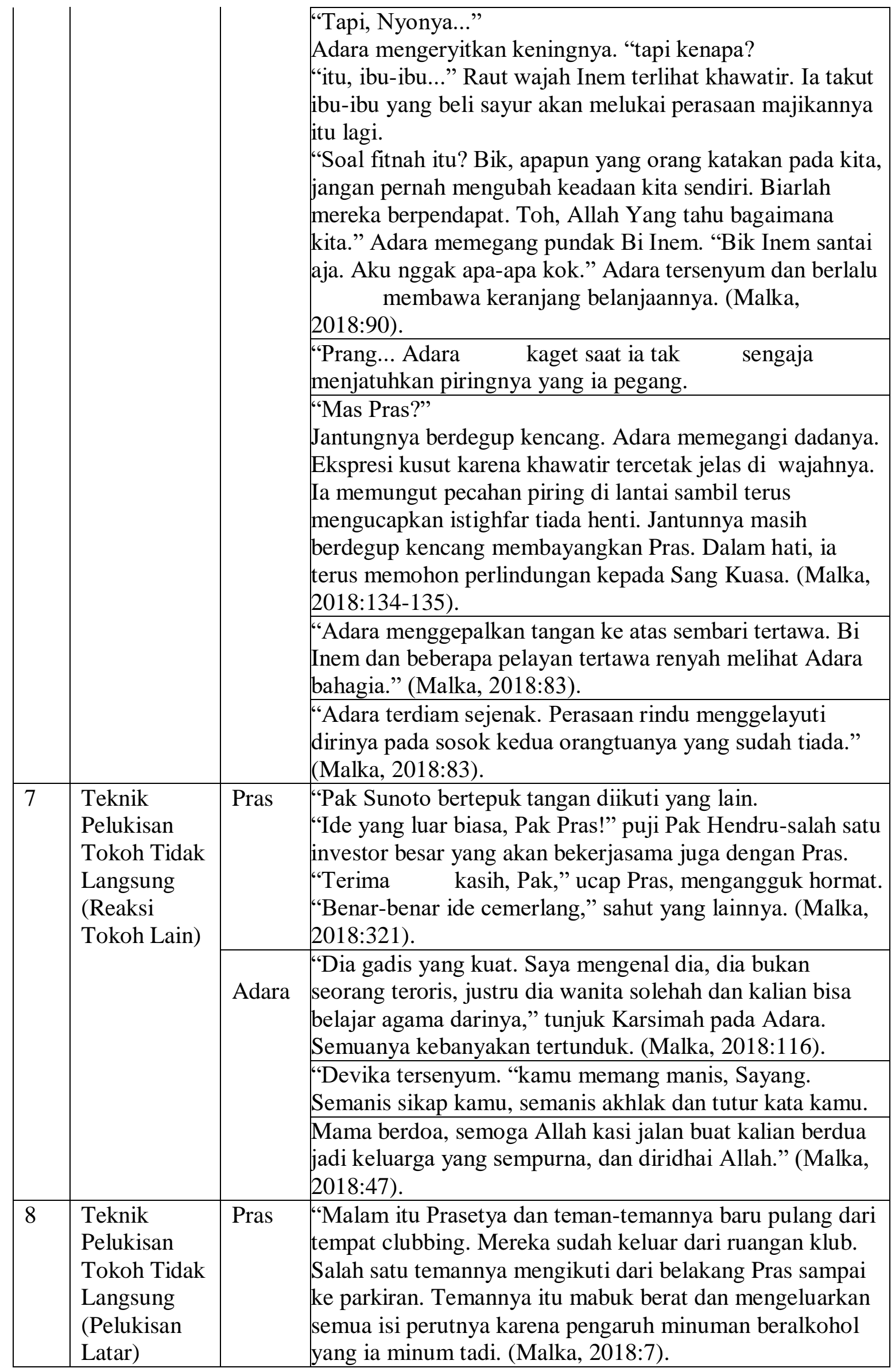




\begin{tabular}{|c|c|c|c|}
\hline & & Adara & $\begin{array}{l}\text { "kamar yang berukuran luas. Tema girlishmewarnai aksen } \\
\text { kamarnya. Jendela bingkai ukiran yang indah bermotif } \\
\text { bunga senada dengan gorden yang berenda bunga dan } \\
\text { bermotif kupu-kupu. Warna peach menjadi warna pilihan } \\
\text { yang mendominasi kamarnya. (Malka, 2018:94). }\end{array}$ \\
\hline & & & $\begin{array}{l}\text { "Adara sendiri mengabdikan diri di pesantren tempat ia } \\
\text { tinggal, dengan mengajarkan ilmu umum yang ia miliki dan } \\
\text { mengecek muroja'ah (hafalan) para santri lain." (Malka, } \\
\text { 2018:27). }\end{array}$ \\
\hline 9 & $\begin{array}{l}\text { Teknik } \\
\text { Pelukisan } \\
\text { Tokoh Tidak } \\
\text { Langsung }\end{array}$ & Pras & $\begin{array}{l}\text { "Prasetya Anggara terlihat gagah dan tampan dengan } \\
\text { setelan kemeja berwarna biru dan celana denim hitamnya. } \\
\text { Tubuh tinggi dengan warna kulit terang menambah } \\
\text { kesempurnaan penampilan fisiknya." (Malka, 2018:8). }\end{array}$ \\
\hline & $\begin{array}{l}\text { (Pelukisan } \\
\text { Fisik) }\end{array}$ & Adara & $\begin{array}{l}\text { "Dari ujung meja nomor sebelas duduk seorang gadis } \\
\text { berkulit putih tengah menukmati minumannya di atas meja. } \\
\text { Dialah Dara-gadis rupawan-idaman setiap pemuda." } \\
\text { (Malka, 2018:55). }\end{array}$ \\
\hline & & & $\begin{array}{l}\text { "Suatu hari mereka bertemu di sebuah kafe. Dara nama } \\
\text { gadis itu. Gadis ramah yang cantik, tinggi, putih, dan } \\
\text { langsing tentunya, yang senyumnya begitu indah untuk } \\
\text { dipandang. Gadis yang sempurna bagi kebanyakan kaum } \\
\text { adam, khususnya Pras." (Malka, 2018:11). }\end{array}$ \\
\hline 10 & $\begin{array}{l}\text { Teknik } \\
\text { Pelukisan } \\
\text { Tokoh Tidak } \\
\text { Langsung } \\
\text { (Catatan }\end{array}$ & Pras & $\begin{array}{l}\text { "Pras semakin mendesah dengan napas tercekat. Bagi Pras, } \\
\text { adara adalah wanita yang penuh teka-teki. Namun ia } \\
\text { acuhkan semua isi pikirannya. Pras menginggkari setiap } \\
\text { benih rasa yang mulai tertancap di hatinya." (Malka, } \\
\text { 2018:167). }\end{array}$ \\
\hline & $\begin{array}{l}\text { Tentang } \\
\text { Identifikasi } \\
\text { Tokoh) }\end{array}$ & & $\begin{array}{l}\text { "Menurutnya, Dara adalah gadis misterius. Nama yang } \\
\text { selama ini membayangi langkahnya. Semua pengawal ia } \\
\text { tugaskan mencari gadis itu. Namun hasilnya nihil." (Malka, } \\
\text { 2018:11). }\end{array}$ \\
\hline
\end{tabular}

Data yang ditemukan terhadap teknik pelukisan langsung sebanyak 15 data, sedangkan data yang ditemukan pada teknik tidak langsung secara sebanyak 57 data. Data yang paling dominan pada teknik tidak langsung adalah data dari teknik tingkah laku sebanyak 12 data. Data yang paling sedikit ditemukan pada teknik tidak langsung adalah teknik pelukisan fisik dan teknik catatan tentang identifikasi tokoh yang berjumlah masingmasing sebanyak 2 data. Kedua teknik yang dipadukan oleh Mawar Malka dalam novel Harapan di Atas Sajadah sesuai dengan penelitian yang dilakukan olehSesilia. Sesilia juga menemukan kedua teknik ini dalam novel Hujan Bulan
Juni yang dilakukan penelitian pada tahun (2015). Akan tetapi, sesilia tidak menemukan data dari teknik pelukisan latar. Perbedaannya terlihat pada teknik pelukisan latar yang peneliti lakukan terdapat data tentang pelukisan latar.

Penelitian yang dilakukan oleh Ucha pada tahun (2016) juga mendapatkan hasil yang sama yaitu mengenai teknik langsung dan teknik tidak langsung. Teknik ini dipadukan oleh Crisna Pabichara dalam novelnya yang berjudul Sepatu Dahlan. Relevansi dengan penelitian ini, Ucha menemukan data tentang catatan identifikasi tokoh melalui prinsip kemiripan dan pertentangan, sedangkan peneliti tidak 
menemukan data dari catatan tentang identifikasi tokoh melalui prinsip kemiripan dan pertentangan. Selanjutnya penelitian yang dilakukan Diono pada tahun (2017). Penelitian ini juga menemukan teknik pelukisan tokoh langsung dan pelukisan tokoh tidak langsung dalam novel Ayah karya Andrea Hirata. Hasil penelitian ini ditemukan enam belas data yang menunjukkan teknik tentang pelukisan tokoh. Data yang dimaksud terdiri dari Teknik langsung sebanyak lima data, teknik cakapan sebanyak enam data, teknik tingkah laku sebanyak tiga data, teknik pikiran dan perasaan sebanyak dua data. Perbedaannya terlihat pada data yang peneliti dapatkan dari semua teknik, sedangkan Diano hanya mendapatkan data dari teknik cakapan, tingkah laku, pikiran dan perasaan.

Penelitian selanjutnya yang dilakukan oleh Asmarani pada tahun (2017). Penelitian ini juga mendapatkan hasil yang sama yaitu mengenai teknik pelukisan tokoh secara langsung dan pelukisan tokoh secara tidak langsung. Kedua teknik ini dipadukan dalam novel Derai Hujan karya Sandra Brown. Relevansi penelitian tersebut dengan penelitian ini dikarenakan Asmarani tidak mendapatkan data dari teknik pelukisan fisik, sedangkan peneliti mendapatkan data tentang teknik pelukisan fisik. Keempat penelitian di atas memiliki persamaan dengan penelitian yang penulis lakukan yaitu tentang penggunaan teori dari Burhan Nurgiyantoro. Namun, perbedaannya terletak pada novel yang dikaji. Seperti yang sudah dijelaskan oleh Nurgiyantoro, Malka sebagai penulis masa kini lebih banyak menggunakan teknik pelukisan tokoh secara tidak langsung. Hal ini dimaksudkan untuk menjabarkan secara jelas mengenai pelukisan tokoh dalam novel Harapan di Atas Sajadah. Melalui teknik ini pengarang tidak mendeskripsikan secara eksplisit kedirian seorang tokoh, melainkan pembaca harus menafsirkan sendiri tentang sifat dan sikap serta tingkah laku dari tokoh yang bersangkutan.Teknik pelukisan tokoh secara tidak langsung lebih efektif dari pada teknik pelukisan tokoh secara langsung. Teknik ini lebih realistis dikarenakan setiap tokoh dalam cerita terdapat perobahan karakter, baik melalui percakapan ataupun melalui perbuatan seorang tokoh.

\section{PENUTUP}

Berdasarkan hasil penelitian yang telah dilakukan, novel Harapan di Atas Sajadah karya Mawar Malka menggunakan teknik pelukisan tokoh. Teknik yang dimaksud adalah teknik pelukisan tokoh secara langsung dan teknik pelukisan tokoh secara tidak langsung. Melalui analisis tentang teknik pelukisan tokoh secara langsung dapat disimpulkan bahwa data yang terdapat pada teknik ini berjumlah 15 data. Sedangkan pada teknik pelukisan tidak langsung terdapat beberapa pembahagian, diantaranya teknik cakapan sebanyak 11 data, teknik tingkah laku sebanyak 12 data, teknik pikiran dan perasaan sebanyak 8 data, teknik arus kesadaran sebanyak 5 data, teknik reaksi tokoh sebanyak 11 data, teknik reaksi tokoh lain sebanyak 3 data, teknik pelukisan latar sebanyak 3 data, teknik pelukisan fisik sebanyak 2 data, selanjutnya teknik catatan tentang identifikasi tokoh sebanyak 2 data.

Keseluruhan data dari teknik tidak langsung berjumlah 57 data. Data yang paling dominan pada teknik pelukisan tidak langsung adalah teknik tingkah laku yang sebanyak 12 data. Data yang paling sedikit pada teknik pelukisan tidak langsung adalah data dari Teknik pelukisan fisik dan data dari catatan tentang dentifikasi tokoh yangberjulah masing-masing sebanyak 2 data. Secara keseluruhan gabungan data dari teknik 
langsung dan teknik tidak langsung berjumlah 72 data.

\section{DAFTAR PUSTAKA}

Afrianti, Iska Hayuni. 2014. Analisis Tokoh dalam Novel Jejak KupuKupu Karya Agnes Jesica dengan Tinjauan Psikologi Sastra. Skripsi (Internet), (http://repository.Unib.Ac.Id). Diakses tanggal 26 September 2019.

Asmarani, $\quad$ Rahmanti. 2017. Penggambaran Tokoh Utama dalam Novel Derai Hujan Karya Sandra Brown. Skripsi (internet), (Http://repositori.utindar.ac.id).

Diakses tanggal 14 Agustus 2019.

Diono, Hana Riani Irma. 2017. Pelukisan Tokoh Antagonis dalam Novel Ayah karya Andrea Hirata dan Implementasi Pembelajarannya di SMA. Skripsi (Internet). (http://repositori.Untidar.Ac.Id). Diakses 15 Juni 2019.

Karmini, Ni Nyoman. 2011. Teori Pengkajian Fiksi dan Drama. Denpasar: Pustaka Larasan.

Kosasih, E. 2014. Jenis-jenis Teks. Bandung: Yrama Widya.

Malka, Mawar. 2018. Harapan di Atas Sajadah. Jakarta: Wahyu Qolbu.

Minderop, Albertine. 2018. Metode Karakterisasi Telaah Fiksi. Jakarta: Yayasan Obor Indonesia.

Na"eim, Nur Arifin. 2016. Analisis Penokohan dalam Novel Anakku Dipotret Malaikat Karya Adnan Katino. Jurnal (Internet). (http:// Jurnal. Untan. Ac. Id/Index. Php/Jpdpb/Article/View/14939).
Nurgiyantoro, Burhan. 2017. Teori Pengkajian Fiksi. Jakarta: Gajah Mada University Press.

Priyambada, Khanif Wahyu. 2017. Analisis Penokohan dan Latar dalam Kinderroman Herrder Diebe karya Cornelia Funke. Skripsi (internet), (http://www. eprints. uny. ac. id). Diakses 15 Agustus 2019.

Rendra, Wicaksono. 2015. Masalah Perjodohan dalam Novel Memang Jodoh Karya Marah Rusli. Skripsi (internet), (http://repository.upi). Diakses tanggal 25 Oktober 2019.

Sesilia, Seli. 2015. Teknik Pelukisan Tokoh dalam Novel Hujan Bulan Juni Karya Sapardi Djoko Damono. Jurnal (internet).(http://jurnal.untan.ac.id /index.php/). Diakses tanggal 20 Juni 2019.

Ucha, Riani. 2016. Analisis Tokoh dan Penokohan dalam Novel Sepatu Dahlan karya Khrisna Pabichara. Jurnal Ilmiah, Volume 1, No.4, Oktober 2016: 144-153.

Wahyuni, Elizabeth. 2017. Analisis Unsur Intrinsik dan Ekstrinsik Novel Surat Kecil Untuk Tuhan Karya Agnes Davonar Sebagai Sumbangan Materi Bagi Pengajaran Sastra. Skripsi (Internet),(http://Repository. UmPalembang. Ac. $\mathrm{Id} / \mathrm{Id} /$ Eprint/1199). Diakses 22 Maret 2019.

Wiyatmi. 2011. Psikologi Sastra Teori dan Aplikasinya. Yogyakarta: Kanwa Publisher. 